Florida International University FIU Digital Commons

FIU Electronic Theses and Dissertations

University Graduate School

3-25-2014

\title{
The Progressive Catholic Church in Brazil, 1964-1972: The Official American View
}

Sigifredo Romero

srome039@fiu.edu

DOI: $10.25148 /$ etd.FI14040878

Follow this and additional works at: https://digitalcommons.fiu.edu/etd

Part of the Christianity Commons, Diplomatic History Commons, History of Christianity Commons, History of Religion Commons, Latin American History Commons, and the Political History Commons

\section{Recommended Citation}

Romero, Sigifredo, "The Progressive Catholic Church in Brazil, 1964-1972: The Official American View" (2014). FIU Electronic Theses and Dissertations. 1210.

https://digitalcommons.fiu.edu/etd/1210

This work is brought to you for free and open access by the University Graduate School at FIU Digital Commons. It has been accepted for inclusion in FIU Electronic Theses and Dissertations by an authorized administrator of FIU Digital Commons. For more information, please contact dcc@fiu.edu. 


\section{FLORIDA INTERNATIONAL UNIVERSITY}

Miami, Florida

THE PROGRESSIVE CATHOLIC CHURCH IN BRAZIL, 1964-1972:

\section{THE OFFICIAL AMERICAN VIEW}

A thesis submitted in partial fulfilment of the

requirements for the degree of

MASTER OF ARTS

in

RELIGIOUS STUDIES

by

Sigifredo Romero

2014 
To: Dean Kenneth G. Furton

College of Arts and sciences

This thesis, written by Sigifredo Romero, and entitled The Progressive Catholic Church in Brazil, 1964-1972: The Official American View, having been approved in respect to style and intellectual content, is referred to you for judgment.

We have read this thesis and recommend that it be approved.

Christine Gudorf

Victor Uribe

Ana Maria Bidegain, Major Professor

Date of Defense: March 25, 2014

The thesis of Sigifredo Romero is approved

Dean Kenneth G. Furton
College of Arts and Sciences

Florida International University, 2014 


\section{DEDICATION}

To Maria Elba, Ana Maria and Mariana; my mother, my professor and my girlfriend. Three different Marias, three souls of Latin America. 


\section{AKNOWLEDGMENTS}

Many people made possible the writing of this thesis, the research and my life in the last two years. First of all, Professor Ana Maria has been the mastermind of the whole enterprise. I am extremely grateful not only for her academic support but also for her generous help in the littlest elements of my life. I would neither have come to her nor to Miami without the paternal concern and the direction of my friend Fernando Torres in Bogotá. The support of my mother, Elba and of my family Romero in Miami namely Anabell Corredor and Fabiola Romero was also vital for my survival since I came to Miami in August of 2012. In the Religious Studies Department of FIU I could count on the generous help of the faculty and the staff.

I also thank the members of the committee, Professor Christine Gudorf and Professor Victor Uribe, for their invaluable suggestions and corrections. In Miami I met extraordinary friends who helped me in any possible way: Michael Brasher and his lovely family, Stephanie Londoño, Alex Huezo, Kiyomi Tsuyuki, Alvin del Valle, Evelyn Arhin-Sam, Helen Tarbatt, Nestor Perez, Katie Pals, Alfonso Matas, and many others. They all made of Miami my home. Thanks to Monica Weeks, in D.C., who hosted me in her home during difficult moments. Thanks, finally, to Mariana Mello for being with me in so many ways. 


\begin{abstract}
OF THE THESIS
THE PROGRESSIVE CATHOLIC CHURCH IN BRAZIL, 1964-1972:
\end{abstract}

THE OFFICIAL AMERICAN VIEW

by

Sigifredo Romero

Florida International University, 2014

Miami, Florida

Professor Ana Maria Bidegain, Major Professor

This thesis explores the American view of the Brazilian Catholic Church through the critical examination of cables produced by the U.S. diplomatic mission in Brazil during the period 1964-1972. This thesis maintains that the United States regarded the progressive catholic movement, and eventually the Church as a whole, as a threat to its security interests. Nonetheless, by the end of 1960s, the American approach changed from suspicion to collaboration as the historical circumstances required so. This thesis sheds light on the significance of the U.S. as a major player in the political conflict that affected Brazil in the 1964-1972 years in which the Brazilian Catholic Church, and particularly its progressive segments, played a fundamental role. 


\section{TABLE OF CONTENTS}

CHAPTER

PAGE

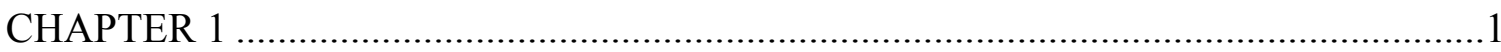

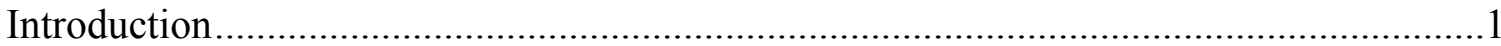

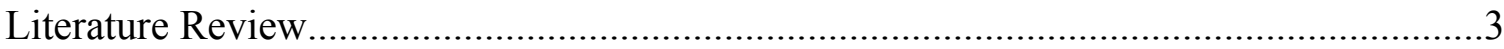

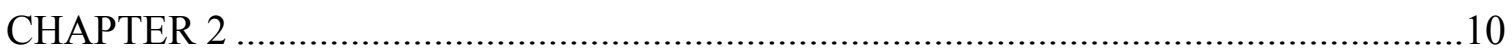

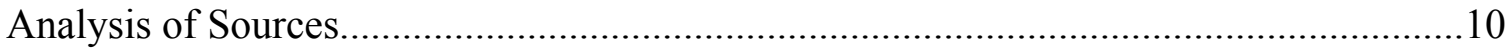

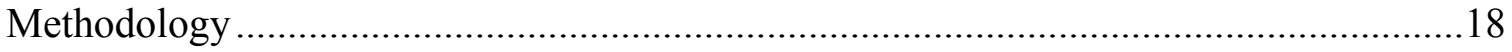

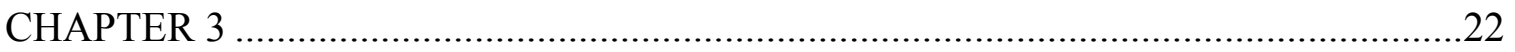

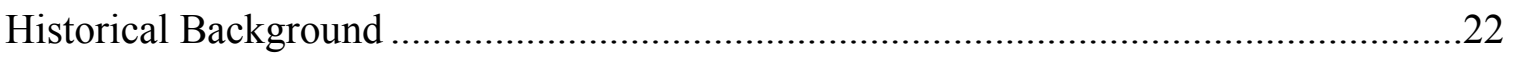

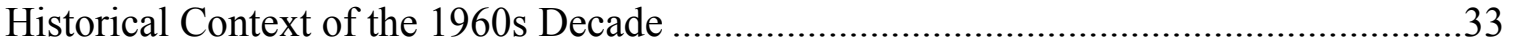

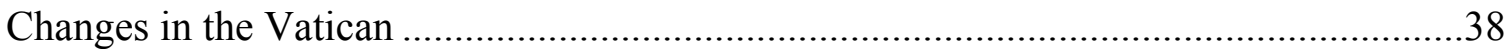

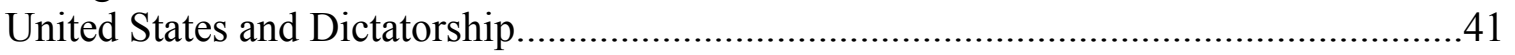

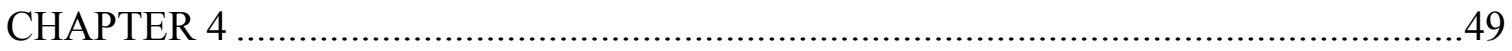

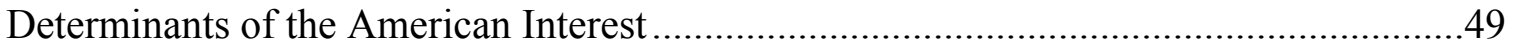

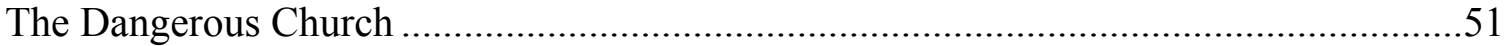

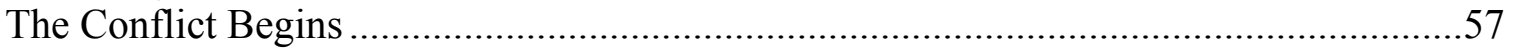

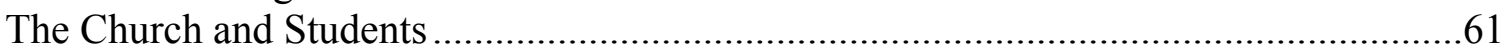

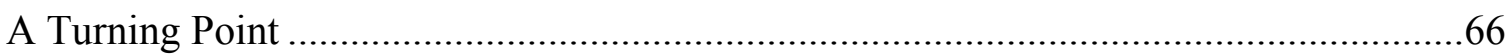

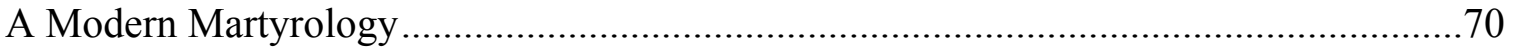

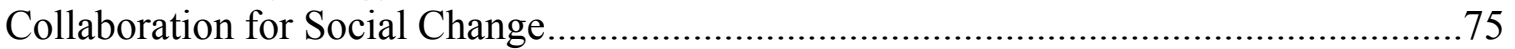

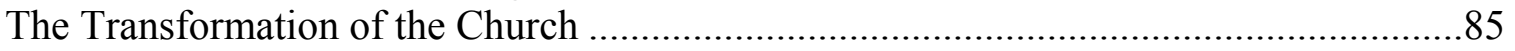

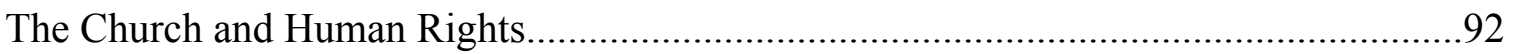

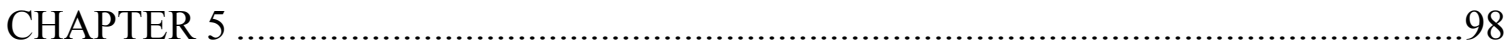

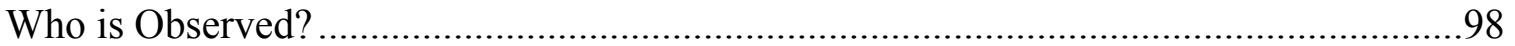

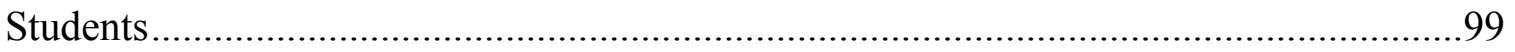

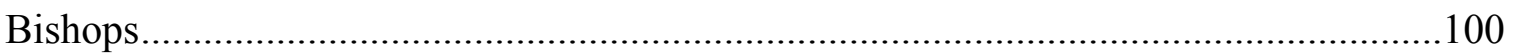

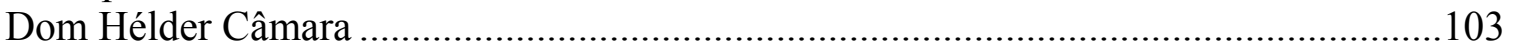

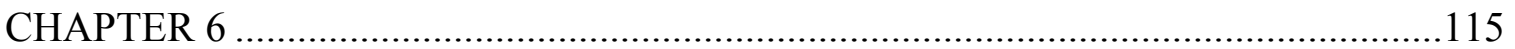

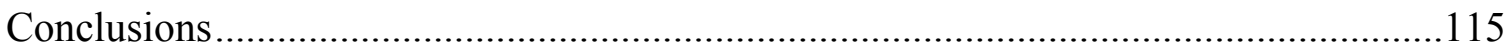

Further Research Possibilities...............................................................................122

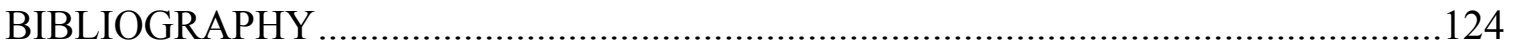

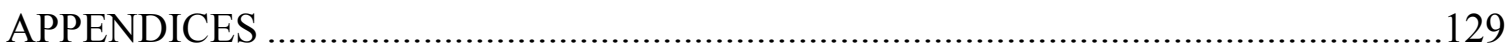




\section{CHAPTER 1}

\section{Introduction}

The role of the Catholic Church in the public life during the military dictatorship that ruled Brazil between 1964 and 1985 has been the object of an important debate in the Brazilian and the brazilianist American historiography. There is no surprise that in that time of important political transformations, the Church played a definitive role. In this thesis I explore the U.S. views and interests in the Brazilian Church during the years 1964-1972, which correspond to the first period of the dictatorship.

The present research is underpinned by the controversial role the United States played in Latin American politics in the decades of the 1960s and 1970s. Particularly in the Southern Cone, those were years marked by the imposition of military dictatorships that were supported by the US. ${ }^{1}$ Those regimes abolished democracy and implemented dirty war policies under which thousands of people were tortured, murdered and disappeared. The Brazilian regime belongs to that tradition and the support it derived from the United States is common knowledge. ${ }^{2}$

\footnotetext{
${ }^{1}$ See William Blum, U.S. Military and CIA Interventions since World War II (Monroe, Me.: Common Courage Press, 2004).

${ }^{2}$ The documents that proved the military support of Lyndon B. Johnson's government to the rebels of 1964 were declassified in 2004 and can be consulted freely. See: "Brazil Marks 40th Anniversary of Military Coup: Declassified documents shed light on U.S. role," National Security Archive, last modified February 9, 2014, http://www2.gwu.edu/ nsarchiv/NSAEBB/NSAEBB118/index.htm
} 
Along with other segments of Brazilian society, the Church was the object of persecution and repression by the military because of the political commitments of some of its members. The persecution led to a bitter confrontation between a major sector of the Brazilian Church and the military government that marked the political life of Brazil during those years. Although the so-called "Church-state relations" are a fundamental piece of the U.S. American view of the progressive Brazilian Church, this research is not limited to "Church-state relations."

Instead, my intention is to understand the United States government's political views, conceptions of and interests in the Brazilian Catholic Church in the years 19641972. Those views and interests seem highly influenced by the ideological context of the time. On one hand, the U.S. discourse of domination over Latin America was marked by its Doctrine of National Security. On the other hand, by that time Brazil was the epicenter of an emergent continental movement within the Catholic Church that challenged U.S. hegemony and was known as Liberationist Christianity. ${ }^{3}$ In this context, the U.S. establishment regarded the progressive wing of the Brazilian Church as a likely threat to the American interests. ${ }^{4}$ Furthermore, the involvement of the CIA and other U.S.

\footnotetext{
${ }^{3}$ I have borrowed the term "Liberationist Christianity" from Michael Löwy. It is, in my opinion, the most appropriate way to describe what is commonly known as "Liberation Theology." See: Michael Löwy, The War of Gods: Religion and politics in Latin America (London: Verso, 1996), 32-33.

${ }^{4}$ See: Richard L. Rubenstein and John K. Roth, The Politics of Latin American Liberation Theology: The challenge to U.S. public policy (Washington, D.C.: Washington Institute Press, 1988).
} 
agencies in the persecution of the liberationist movement has already been subject of research. $^{5}$

The present study focuses on the cables of the U.S. Foreign Mission in Brazil that deal with the Church during the years 1964-1972 and analyses them in light of the ideological trends and the political conflicts of the time. As a whole those documents will be interpreted with a view to clarifying the perceptions, views and interests that surely had an impact in US American foreign policy in Brazil. Taking into account that these sources were hitherto unused, my hope is that this paper will add to a better comprehension of the US role in the religious-political transformations of the last decades in Brazil.

\section{Literature Review}

There is an important number of works and contributions to the different fields in which this work is located. Repression, political persecution and the relation between the military regime and the opposition has been the subject of important debates since the very time of the dictatorship. State and Opposition in Military Brazil by Maria Helena Moreira Alves of 1985, and the diverse reports of the Brazilian Peace and Justice Commission are just two conspicuous examples. ${ }^{6}$

\footnotetext{
${ }^{5}$ See: Penny Lernoux, Cry of the People: United States involvement in the rise of fascism, torture, and murder and the persecution of the Catholic Church in Latin America (Garden City, NY: Doubleday \& Company, 1980).

${ }^{6}$ Maria Helena Moreira Alves, State and Opposition in Military Brazil (Austin: University of Texas Press, 1985).
} 
The most recent important contribution concerning U.S. participation in the coup d'état of 1964 and its support of the subsequent military regime came in 2008 with $O$ Grande Irmão: Da operação brother Sam aos anos do chumbo by Carlos Fico. ${ }^{7}$ In the review of the literature I will refer to the literature on the narrower field of the Catholic Church in its political dimension during the first half of the dictatorship which has very often been understood as Church-state relations.

A first important contribution in this regard came in 1971 as L'Eglise et le Pouvoir au Brésil, translated to English in 1973 as Church and Power in Brazil. ${ }^{8}$ The author, the French priest Charles Antoine, was a protagonist of the events, who was forced to leave Brazil in 1969 as a result of government persecution. Antoine offers a very detailed account and a clear understanding of the evolution of the Church's role and the political conflict with the military during the first five years of dictatorship. Very significant events came after Church and Power in Brazil, events that would redefine the 1964-1969 period of Church-state relations but Antoine's contribution remains relevant.

The characteristics of Antoine's work would be present in most of the historiography of the Church under the dictatorship. Firstly, since the Church-state confrontation of the 1960s was a media phenomenon, newspapers and journals have been a most important source of data. The press not only published stories on arrests of priests and judiciary processes, but also used to publish the declarations and letters of bishops verbatim. On the other hand, as a result of the military censorship and persecution of the

\footnotetext{
${ }^{7}$ Carlos Fico, O Grande Irmão: Da operação Brother Sam aos anos de chumbo: O governo dos Estados Unidos e a ditadura militar brasileira (Rio de Janeiro: Civilização Brasileira, 2008).

${ }^{8}$ Charles Antoine, Church and Power in Brazil (Maryknoll, NY.: Orbis Books, 1973).
} 
intellectual sectors of Brazilian society, many of the contributions from those opposing the military government to the field come from overseas.

Brazilian and Latin American efforts to understand this period of the Church have focused on the different elements that form and explain Liberationist Christianity. Some authors focus on Catholic Action and the student movement, ${ }^{9}$ others on the Basic Ecclesial Communities, ${ }^{10}$ and yet others explain the emergence of Liberationist Christianity as a continental process. ${ }^{11}$ Those phenomena, and particularly the political aspect of the Church, have attracted the attention of American researchers as well. Interest intensified by the end of the 1970s following the prominence of the Church in the defense of human rights and the participation of Christians in the Sandinista revolution of Nicaragua.

That is the framework for Cry of the People by journalist Penny Lernoux (see note 5). Published in 1980, the book focuses on the struggle of important elements of Catholic Church for the defense of human rights and a more egalitarian Latin America. Lernoux sheds light on the persecution of progressive Christians by a conglomerate of U.S. agencies, Latin American governments and transnational corporations, among

\footnotetext{
${ }^{9}$ See: Ana María Bidegain, La Organización de Movimientos de Juventud de Acción Católica en América Latina: Los casos de los obreros y universitarios en Brasil y Colombia entre 1930 - 1955, parte III (Brasil) (PhD diss., Catholic University of Lovaina, 1979). Also: Luiz Alberto Gómez de Souza, A JUC: Os estudantes católicos e a política (Petrópolis: Vozes, 1984).

${ }^{10}$ Recent works about the Basic Ecclesial Communities have brought new interpretations. For a study with gender perspective, see: Carol Drogus, Women, Religion, and Social Change in Brazil's Popular Church (Notre Dame, IN.: University of Notre Dame Press, 1997). For an understanding of the decline of the communities, see: Manuel Vásquez, The Brazilian Popular Church and the Crisis of Modernity (Cambridge: Cambridge University Press, 1998).

${ }^{11}$ For a longue durée interpretation, see: Enrique Dussel, A History of the Church in Latin America: Colonialism to liberation (Grand Rapids, MI.: William B. Eerdmans, 1981). For a most recent and comprehensive view, see: Löwy, The War of Gods.
} 
others. Cry of the People has become a classic in the field for the breadth of its research, the multiplicity of facts involved and the braveness of an author who denounces the crimes of powerful institutions. Moreover, Lernoux brings new data and sources from several documental niches, including the U.S. Congress, Amnesty International and the documentation service of the U.S Conference of Catholic Bishops.

American brazilianist scholarship on the Catholic Church was also vitalized in the 1970s and 1980s decade. Among the authors who best know the Church during the dictatorship Thomas Bruneau, Scott Mainwaring, Ralph Della Cava; and, more recently, James Green and Kenneth Serbin, stand out. An early effort by an U.S. American researcher to explain the situation of the Church in the 1960s decade was Thomas Bruneau's The Political Transformation of the Brazilian Catholic Church, published in $1974^{12}$ which was followed in 1982 by The Church in Brazil: The politics of religion. ${ }^{13}$ While the first is a historical account that explains the ideological changes within the Church, the second, by the time it was published, was a synchronic analysis of the institution.

In 1986 Scott Mainwaring contributed to the debate with The Catholic Church and Politics in Brazil 1916-1985, a work which followed the same pattern of diachronic historical account as The Political Transformation, but also included the 1974-1985

\footnotetext{
${ }^{12}$ Thomas Bruneau, The Political Transformation of the Brazilian Catholic Church (London: Cambridge University Press, 1974).

${ }^{13}$ Thomas Bruneau, The Church in Brazil: The politics of religion (Austin: University of Texas Press, 1982).
} 
period, not covered by Bruneau. ${ }^{14}$ The political performance of the Church during 19741985, period known as abertura, was also covered by the recognized brazilianist Ralph Della Cava in a working paper published by the Kellogg Institute in 1988, The Church and the Abertura in Brazil 1974-1985. ${ }^{15}$

Twenty-seven years passed between Antoine's book and Kenneth Serbin's article "Anatomy of a Death," published in the Journal of Latin American Studies in 1998. ${ }^{16}$ Serbin examines the assassination of student Alexandre Vannucchi Leme in 1973 and the Church-state crisis that this event provoked. "Anatomy of a Death" is interesting, among other factors, because it brings up the importance of the Vatican as an actor in the political conflict. Moreover, Serbin analyses the Bipartite Commission, a space for a high level negotiation between the Brazilian bishops and military in the1970-1974 years.

Precisely the Bipartite Commission would be the subject, two years later, of Secret Dialogues that explores new dimensions in the political role of the Church and its relation with the military. ${ }^{17}$ Serbin's findings were possible because of new sources like the archives of the repressive apparatus of São Paulo and Rio de Janeiro that were opened to research by the mid-1990s, and documents of the Bipartite Commission, unsealed since 1992 by General Antonio Carlos da Silva Muricy.

\footnotetext{
${ }^{14}$ Scott Mainwaring, The Catholic Church and Politics in Brazil, 1916-1985 (Stanford: Stanford University Press, 1986).

${ }^{15}$ Ralph Della Cava, The Church and the Abertura in Brazil, 1974-1985 (Notre Dame, IN.: Helen Kellogg Institute for International Studies, University of Notre Dame, 1988).

${ }^{16}$ Kenneth Serbin, "The Anatomy of a Death: Repression, human rights and the case of Alexandre Vannucchi Leme in authoritarian Brazil," Journal of Latin American Studies, Vol. 30, No. 1 (Feb., 1998): $1-33$.

${ }^{17}$ Kenneth Serbin, Secret Dialogues: Church-state relations, torture, and social justice in authoritarian Brazil (Pittsburgh, Pa.: University of Pittsburgh Press, 2000).
} 
Besides Serbin, there has been in the last years another important contribution to the understanding of the role of the church under the dictatorship. James Green's We Cannot Remain Silent of 2010 is the first research in the field carried out after the declassification of the documents that proved the U.S. government's involvement in the coup of 1964, which is an integral part of the book. ${ }^{18}$ However, that is not the subject of We Cannot Remain Silent; rather the focus is the social movement that emerged in the U.S. against the Brazilian dictatorship. The movement made a campaign of information about human rights violations in Brazil and constituted a pressure group working to make Washington change its policy of complicity. U.S. and Brazilian, Protestant and Catholic religious networks would be determinant in this movement.

Taking into account the works already published and the development of the debate, my thesis can contribute to the understanding of the international relevance of the Catholic Church, its conflict with the military regime and the position of the United States. Moreover, there is a longstanding need to introduce into the debate the sort of sources that have been used here. The second chapter of this thesis is composed of a basic and necessary examination of the sources, and includes a methodological outline of the entire research. The third chapter is a historical contextualization that brings together all the elements of the subject: the political role of the Church in Brazil, factors in understanding the military dictatorship and the role of the U.S. in Brazilian affairs. The fourth and fifth chapters are the core of this paper. In the fourth chapter, the sources are interpreted with a diachronic approach that results in a narrative of the history of the

\footnotetext{
${ }^{18}$ James Green, We Cannot Remain Silent: Opposition to the Brazilian military dictatorship in the United States (Durham, NC.: Duke University Press, 2010).
} 
Church in the 1964-1972 period from the American standpoint. The fifth chapter utilizes the sources from a rather synchronic standpoint that takes into consideration and stresses elements that would go unnoticed in the previous chapter. In the sixth chapter I present the conclusions and suggest further research possibilities. 


\title{
CHAPTER 2
}

\begin{abstract}
Analysis of Sources
The originality of this research lies in the study of largely unused primary sources. The contextualization and interpretation of those sources provide the narrative and argument of my thesis. Therefore, it is imperative to undertake a most basic documental analysis of the sources and make clear the methodological framework used to interpret them.
\end{abstract}

Communication has been consubstantial to any form of political power. It is a fundamental element for the development and consolidation of inner institutions as much as for the relations with external forces. At least since Pharaonic epochs, rulers established external relations through ambassadors and jealously guarded their records as did the Venetian doges, the popes and all sorts of political leaders. ${ }^{19}$ The rigorous and academic study of that sort of documentation is known as diplomatics. ${ }^{20}$

\footnotetext{
${ }^{19}$ William Moran et al., Les Letres d'el-Amarna: Correspondance diplomatique du pharaon (Paris: Ed. Du Cerf, 1987), 17-21. Cited in : Constance Vilar, Le Discours Diplomatique (Paris: Université de Bordeaux et L'Harmattan, 2008), 84.

${ }^{20}$ The term comes from the Greek diploi that means "folded" and originally referred to the documents that were delivered to the soldiers of the Roman Empire when they were licensed. The term was later applied for extension to any solemn document. In the seventeenth century Jean Mabillon (1632-1707) founded the discipline of diplomatics by doing extensive research to determine the authenticity of mediaeval documents. Along with paleography, also developed by Mabillon, diplomatics became a fundamental pillar of history.
} 
The modern diplomatic discourse that emerged with the Peace of Westphalia (1648) is built upon the reciprocity of diplomatic relations and the respectability of the diplomats whose immunity every contemporary state is supposed to recognize. Represent, negotiate and observe are the three basic functions of any diplomatic service. In practice, however, the difference between observation and espionage is blurred, hence the informal "honorable spies" attributed to seventeenth century ambassadors. In principle, the legality of the means used to obtain the information is the basis for discriminating between observation and espionage. Albeit, the difference is unclear especially in times of crisis and has led to no few problems among rival nations through history. ${ }^{21}$

It is worth noting that the diplomatic capacity of a state, just like its military strength, depends on its economic superiority. Moreover, in a relation of dependence very often the satellite state assumes an ambiguous attitude towards espionage on its own soil. Sometimes, when subordinate nations deal with a real or constructed threat from an internal enemy, they even accept information gathered by external forces. Precisely that scenario could have been possible for the U.S.-Brazil diplomatic relations during the dictatorship.

The 1960s and 1970s were far removed from the technological advances that have since made the U.S. National Security Agency (NSA) one of the largest intelligence organizations of the world. Given the lack of current day technology, during those years the diplomatic corps were the eyes and ears of the United States government abroad.

${ }^{21}$ Vilar, Le Discours Diplomatique, 94-115. 
Furthermore, the U.S. had and still has the most robust Foreign Service in the world and its functionaries emit a huge amount of information every day. Cables are the official way of communication for ambassadors, consuls and reporting officers and have been an important source of information for historians.

The U.S. Foreign Service cables deal with several topics. They report about economic and political events, situations and tendencies and all of this, of course, paying particular attention to the interests and security of the United States. Regarding politics, by the 1964-1972 years, the Foreign Mission in Brazil reported mainly about the changes in the balance of power of the regime, alterations of the public order, student and labor movements, political repression, human rights violations, the Catholic Church and its conflicts with the state.

The information and analysis provided eventually have an impact in the international policy of the U.S. government and its diplomatic relations. ${ }^{22}$ But the cables do not only go to the Department of State; they also inform other diplomatic missions around the globe and different U.S. agencies and departments including the CIA and the Pentagon in cases of National Security issues. All the information of the Service is kept and preserved by the National Archives and Records Administration (NARA), today the largest state archive in the world. NARA states:

American foreign affairs is [sic] a key issue in United States history. The Department of State is designated to lead in the overall direction, coordination, and supervision of American foreign

\footnotetext{
${ }^{22}$ Peter W. Galbraith, "How to Write a Cable: A veteran diplomat explains how it's really done," Foreign Policy, February 22, 2011. Accessed February 9, 2014, http://www.foreignpolicy.com/articles/2011/02/22/ how to write a cable. Clearly, cables and communications about internal affairs of the embassies, visas etc., are completely out of consideration in this study.
} 
policy and foreign relations. Since World War II, a community of agencies has evolved to deal specifically with foreign policy issues. In addition, many other agencies have taken on important roles in American national security affairs. ${ }^{23}$

During the spring-break of 2013, Professor Ana Maria Bidegain and I, with the support of the Department of Religious Studies, did an extensive research at the National Archives in College Park, Maryland. We ran straight into the section "U.S. Embassy, Brasilia" in the collection "Records of the Foreign Service Posts of the Department of State". Those records consist mainly of unclassified and declassified cables from the diplomatic posts in Brazil.

We picked up all the documents that deal with the Catholic Church between 1964 and 1972. A total of 167 documental packets, saved in 13 boxes, for a total of 552 pages were selected, photographed and classified. Every packet is constituted by a single cabledocument, though some of them contain two or three enclosures composed of memorandum of conversations, quantitative data, copies of speeches and public declarations etc. In my research, those enclosures are not treated as independent documents since they make sense only with the other parts of the cable to which they are attached. The average number of pages per cable is 3.5 , and only two of them exceeded 20 pages.

All the cables are composed of basically four parts. First comes the head that can take one third or the whole first page; it is devoted to the technical information of the

23 "Foreign Affairs and International Topics," National Archives, last modified February 9, 2014, http://www.archives.gov/research/foreign-policy/index.html 
cable including remittent, addressee, location, date, and the topic explained in a few words. Right after the head, the reporting officer writes a few lines or paragraphs summarizing the content of the cable so those who read it can know the topic without having to read the whole document. After this comes the body of the document. In the case of long cables, this takes several sections; very short cables, like telegrams, do not go beyond a few lines.

Finally, at the end of the longest cables the officers usually write a few lines entitled "comments" that contains very concise analysis of the situation described. For analytical purposes this is the most important part of the document, since it adds the personal interpretation of the redactor of a document. The comments nuance what the press reports and go further into the meaning of particular facts. On no few occasions, the comments of the redactor include predictions on the behavior of the actors and on the development of the events in the short term. For analytical purposes I have classified the documents into four types.

Telegrams. From the 167 cables, 70 are telegrams that contain a total of 103 pages. Telegrams tend to be the shortest type, and rarely exceed three pages. The telegram is the fastest way of communication and is, in general, used to send information about the important news of the moment or very specific events. Thus the analytical potential of a telegram is not extraordinary and sometimes the information they contain does not add much to what the redactor has taken from news and other sources of information. ${ }^{24}$

\footnotetext{
${ }^{24}$ The reader might notice missing words in some of the citations. This is consequence of the telegram style that shortens the language and omits prepositions.
} 
Reports of Conversations. The next important type of document in terms of quantity is the Report of Conversation and there are 50 of this kind. 38 of them contain a total of 43 Memorandums of Conversations which are enclosures with a particular structure that includes, in the first page, the participants, date, place and subject of the dialogue. The remaining 12 cables have a rather free redaction structure but still refer to specific conversations and interviews. All in all, the reports refer to 55 conversations for a total of 191 pages.

Reports of conversations are used by the diplomatic officers to summarize informal conversations with key individuals of Brazilian politics. The officers invariably deliver an assessment of their interviewees, their relevance, temper and usually political positions. For instance, regarding a certain bishop, the officer may say that he is usually held to be a progressive, that he is intelligent but risky, etc. The reported conversations were sometimes the consequence of furtive and informal meetings where more than one person took part; some were even held by telephone.

From the 55 conversations 51 focus on the Church as the central matter. The remaining four deal only obliquely with it but are dedicated to other topics like the student movement or the political polarization. A total of 57 people participated in conversations with American officers, including 15 bishops, 19 priests (eight of them Americans), one source in the Vatican Curia and four Catholic intellectuals, journalists and professors. In contrast, only six military, three generals and three colonels, 
participated. $^{25}$ The remaining 12 recounted conversations with non-Catholic students, intellectuals and politicians.

All kinds of cables, but particularly the reports of conversations, establish important guidelines for the routes of diplomatic relations between the U.S. and other countries. Through the cables the American government gets to know who is important in a specific moment or situation and who is open to establish a collaborative relation. To certain extent, to have a conversation with an American diplomat means talking to the U.S. administration. Furthermore, people who regularly speak with the officers have more chances to be regarded as an important interlocutor by the higher circles of the government. In this way, bishops Dom Hélder Câmara, Dom Eugênio Sales and Dom Agnelo Rossi, who were interviewed many times, must have been taken seriously by Washington.

The reason for the numerous interviews with U.S. priests is not difficult to understand. On the one hand, out of a historical deficit of churchmen, foreign priests, including U.S. Americans, were a very important part of the Brazilian clergy and many of them reached prominence. On the other, it stands to reason that American officers in foreign countries actively seek to dialogue with people they can better understand, such as their fellow citizens.

Reports. The third group of cable I have used is called simply "report," there are 37 of them. Nonetheless, it is the biggest group in number of pages with 235 as a whole. The

${ }^{25}$ This is in conversations in which the Catholic Church was brought up. Most likely, the American officers had many more conversations with the military but not all of them would have had the Church as one of the topics. Moreover, conversations with members of the high circles of military power would deal with sensitive information that remains classified. 
report is the most standardized of the cables and is mainly used to provide information with a deeper analysis than the telegram. In order to better understand this type of cable, I have classified them as 1) periodical reports, 2) major reports, 3) minor reports and 4) reports about speeches and public declarations.

There are four periodical reports that inform about a broad range of topics including the student movement, the balance of power within Church and military and similar overviews. The period that these reports cover vary between one week and six months. On the other hand, there are four major reports which are documents of more than 10 pages and constitute the type of report most complete, best structured and most deeply thought out. Conversely, the minor reports deal with specific events and news; there are 17 of them. Finally, there are 12 reports that inform about speeches and public declarations mainly from the Episcopal Conference or individual bishops. In the political confrontation between Church and military, speeches, interviews and public declarations acquired an important political weight.

Others. The remaining 10 documents evade an easy classification. There are seven telegrams headed "Department of State" that contain instructions and requests from Washington. There is also a small group of three cables of different types. The first is a biographical data form about bishop Dom Jerônimo de Sá Cavalcante, administrator of the São Bento convent in Salvador de Bahia; the second is a single page called "Memorandum of the files" that seems to belong to a bigger documental packet which was lost in the records; the last one is a telegram headed "airgram." 


\section{Methodology}

Given that my sources are kept in the official archive of the U.S. government, authenticity does not represent a problem. Yet, veracity could still be called into question. Prior to the redaction of any cable, the data and facts obtained by the reporting officer went through personal processes of comprehension and interpretation. Thus the veracity of the material must be questioned. In my thesis, the information is interpreted taking advantage of the historical distance, taking into account the context of the document, and confronting the data with other primary and secondary sources. All of that is knowledge the officer did not have. However, this sort of analysis does not account for the main point of this research. The objective here is neither revealing new facts nor falsifying the existent historical data but rather to proceed in a discursive analysis of the sources in order to understand the ideological position of the subject who writes.

The documents used for my research are selected, classified and analyzed in order to extrapolate the constitutive elements of the U.S. American views and interests in the Brazilian Catholic Church. I have tried, as much as I could, to let the documents speak for themselves. Therefore, the research took the course that the sources suggested, so to speak; the diachronic analysis prevailed and constitutes the backbone of the study. Consequently most of the next chapter is a chronological account that explores the variations of the American view of the Church along the years. A second variable of the analysis was thematic. I chose the most constant subjects of interest for the Foreign Service and did a brief examination of them in the fifth chapter. I have made use of secondary sources, some of them cited in the literary review that focus on those particular 
themes: Church-state relations, human rights, the student movement, bishop Dom Hélder Câmara, etc. In doing all of this, I have resorted to hermeneutics, discursive analysis and comparative methods for historical purposes.

Although the cables that serve as the foundation for this study are intended to be objective descriptions of reality, as any human expression, they reveal important things about those who wrote them. When a diplomatic officer starts a conversation, and when he sits to write the report, he is acting as an employee of his country. In both cases, the function of the officer is to safeguard American interests. I will give one example of the sort of analytical process that I have applied to these documents. On March 26 of 1969 the political officer Richard H. Melton wrote a cable concerning a conversation he had held two days earlier with the writer and anthropologist Gilberto Freyre. The conversation was actually an interview made by a correspondent of the Chicago Daily News in which Melton participated. In his report, the officer wrote, paraphrasing Freyre:

The Church in Brazil is going through a spiritual crisis. People like Dom Hélder err in thinking that the Church should devote itself exclusively to social concerns while neglecting the mystical aspect of religion. Communists would like to use Dom Hélder as a vehicle to capture power, and he is vain enough to accept their support. ${ }^{26}$

To this remarkable comment, more than one level of analysis can be applied. First of all, there is no need to think that the officer is not paraphrasing Freyre. The ideological differences between Freyre and Dom Hélder were well known, so it is very likely that the anthropologist would refer to the bishop in those terms.

\footnotetext{
${ }^{26}$ Report of conversation, Recife, March 26, 1969, State Department Cables, U.S. Embassy, Brasilia, National Archives, box 30.
} 
Nevertheless it is worth reflecting on the capacity of the officer to lead the conversation to certain fields. When the officer asks his interviewee for his opinions about the Church, he is already influencing in the final result of the conversation and hence in the final report. ${ }^{27}$ Unfortunately, the officers did not write their reports of conversations with question-answer structure. Yet nothing stops me from assuming that a report of conversation actually refers to a conversation and not to a monologue in which the diplomatic officer is just a receptacle of information.

While the reporting officer might or might not have had an active role in the conversation itself, the exercise of writing the report is completely his. This conversation took place on March 24 but the report was not sent until March 26. When writing the cable, the officer clarified that he used the notes of the journalist which means that between the conversation and the writing of the report there was a period of time that may have been up to two days. It is worth considering the mental process of the officer during this period of time and how his own ideas and interests would have found their way through the writing of the report.

The personal ideas and interests of the officer, when talking to Freyre and when writing the report, helped give form to the final cable, ergo to the American view of the Catholic Church. The officer does not only have an active role in the conversation, and the capacity to change the word "progressive" for "controversial" or "polemic" in the

\footnotetext{
${ }^{27}$ This may not have been the case in this particular conversation, due to the presence of the journalist, who must have had a more active role than Melton. Yet the question remains important for the 48 reports of conversation that have been taken into account for this research.
} 
report. He also has a role in selecting the information he collected, leaving out what he considers unimportant and stressing what he considers relevant.

For the officer Melton it was important to say (that Freyre said) that Dom Hélder Câmara could eventually become a vehicle of communism. That was important information to share. To conclude, even though it seems that the officer is only transmitting the opinion of one of the most important intellectuals in Brazilian history, he is in fact sending an alert to Washington regarding the dangerousness of Dom Hélder to U.S. interests. 


\section{CHAPTER 3}

\section{Historical Background}

Brazilian history and society stands off from Spanish-speaking America. Language and immense natural barriers have contributed to the isolation of Brazil from the rest of the subcontinent. Furthermore, Brazilian processes of colonization, independence and social change have been carried out in very different ways. One of the most conspicuous elements of the difference is the compromising character of those processes. In comparison to the sociological violence of countries like Mexico and Colombia, or the political polarization of Chile and Argentina, Brazil, where neither violence nor polarization are absent, presents a record more of accommodation. The Brazilian Catholic Church and its role in the political realm are singular as well.

The Church had not played nearly the same role to consolidate absolutism in Portugal as it did in Spain. Hence it had a less important role in the imposition of the colonial apparatus in Brazil. Furthermore, in a territory almost as large as the rest of South America, the Catholic Church experienced serious difficulties in covering Brazil with priests and missionaries and developing the diocesan structures. Yet the Church was

a fundamental pillar of Brazilian society during the colonial times. With the 
establishment of the independent Empire of Brazil in 1822, and particularly under the reign of Pedro II (1831-1889), the Church became entirely subjected to the state. ${ }^{28}$

Later on, with the advent of the republic in 1889, state and Church separated and the latter was left outside of the official public realm. For the political elites that had enthusiastically embraced the European ideologies of progress and secularization the Church did not represent a sufficiently modern institution for a new Brazil. For the Church, on the other hand, splitting from the state meant achieving independence.

During the1920s, as the nation underwent deep economic changes and a decline of the republican order, the Church advanced in its unification and started gaining importance in the public realm again. Both processes were tied to the leadership of Dom Sebastião Leme da Silveira Cintra, better known as Dom Leme (1882-1942), archbishop of Olinda and Recife since 1918, of Rio de Janeiro since 1930 and first Latin American cardinal. Under his guidance, the different dioceses in which the Church was divided at the time started having a common agenda.

Dom Leme wanted to gain for the Church a leading role in the political space without becoming a client of the state. He also endeavored to re-Christianize the Brazilian elites that, in his opinion, had fallen to modern ideologies. ${ }^{29}$ Dom Leme focused on reorganizing the laical associations in existence and developing a Catholic

\footnotetext{
${ }^{28}$ Bruneau, The Political Transformation, 22.

${ }^{29}$ August Comte's positivism, for instance, did not have more influence in any other country outside France than in Brazil. Ordem e progresso (order and progress), the motto of the Brazilian flag, was inspired by positivism.
} 
intelligentsia. ${ }^{30}$ His policies were in agreement with the transformations of the Church in Europe.

As part of the process of modernity, liberal and socialist metanarratives and movements had been emptying Catholicism of followers and power. Towards the end of the nineteenth century the Church finally gathered new impulses to reestablish its lost connection with the city of man. However, in order to survive in a modern world, it had to embrace some modern ways. For instance, to fight against liberalism and socialism, the adoption of organizational processes typical of those movements was necessary.

That is how in the second half of the nineteenth century there had emerged in Europe, Catholic unions, parties and movements of lay persons active in pastoral activities; the latter would be eventually known as Catholic Action, a movement which had started in Italy. Within Catholic Action, lay people, particularly young students and workers, were called to have a more active role in the conservation and expansion of the Church, though under the strict rule of the hierarchy. In this way the clergy was able to penetrate spaces from which the Church had been banished during the process of secularization. In terms of hierarchical structure and conception of the world, this sort of organization was highly conservative. That was the kind of Catholic Action that, with the support of Dom Leme, was introduced to Brazil in the 1920s. ${ }^{31}$ The experiment would prove successful in a country with a historical lack of clergy.

\footnotetext{
${ }^{30}$ Bidegain, La Organización de Movimientos, 40.

${ }^{31}$ Ibid., 84.
} 
In order to promote Catholic ideology, in 1922 Dom Leme and the Catholic leader Jackson de Figuereido founded the Dom Vital Center. The Center was frequented by ardent integralistas who, via the $A$ Ordem journal, disseminated reactionary religiouspolitical ideas. ${ }^{32}$ Both the development of a Catholic intelligentsia and the spread of lay organizations like Catholic Action strengthened the position of the Church in the public realm during the 1920s and paved the way for the reconciliation with the state in the 1930s.

In October of 1930 a revolution led by Getúlio Vargas took power and put an end to the republic. During the next 15 years of Vargas' rule, Brazil lived through enormous advances in industrialization, modernization and a significant expansion of the economy. ${ }^{33}$ As the cities grew, the middle classes and the proletariat, precisely the basis of Vargas' political support, strengthened numerically and politically. In the case of the workers, Vargas stimulated the growth of labor unions under the strict control of the state and in 1932 promulgated a law that allowed working women to vote. ${ }^{34}$

Although Vargas faced significant opposition including armed insurrections, the 1930s was a period of optimism and national pride. Arts and popular culture flourished as musicians and intellectuals produced works and interpreted their times with keen national

\footnotetext{
${ }^{32}$ Mainwaring, The Catholic Church, 31. Integralismo was a conservative political doctrine of nationalist and corporatist character that became successful mainly in Portugal and Brazil; it is usually referred to as a sort of Catholic, Iberian fascism.

${ }^{33}$ Vargas ruled plainly as chief of government until 1934 when he was elected president by the congress. In 1937 he abolished democratic institutions and ruled as dictator until his defenestration in 1945 in a period known as the Estado Novo. Later he would be elected president in 1950. This term ended with a political crisis that led to his suicide.

${ }^{34}$ Bradford Burns, A History of Brazil (New York: Columbia University Press, 1993), 352.
} 
fervor. At the same time, the ambitions and worldview of Brazilians acquired a renewed cosmopolitan character while the education system modernized and expanded from basic to higher level.

Nonetheless, the Vargas' era was also characterized by centralization and concentration of power in the hands of Vargas. Despite the undeniable authoritarian and at times fascist character of his government that drew on censorship and the outlawing of movements such as communism and integralismo, Vargas followed the compromising trend of Brazilian political history. ${ }^{35} \mathrm{He}$ maintained relations with the coffee-based elites and the industrialists, ruled for the middle class and the proletariat and was supported by both military and churchmen.

During the 1930s Church and state reintegrated and provided incommensurable services to each other. Dom Leme had played a fundamental role in Vargas' rule from the very beginning. In the days of the revolution, the bishop served as a mediator and facilitated the removal from power of President Washington Luís ergo the ascension of Vargas. In 1931 Dom Leme organized monumental mobilizations of devotion to Our Lady of Aparecida and the statue of Christ the Redeemer was inaugurated in Rio. Nowadays both are powerful symbols of the presence of the Church in quotidian life through which Brazil is configured as a Catholic nation. ${ }^{36}$

\footnotetext{
${ }^{35}$ Burns, A History of Brazil, 347.

${ }^{36}$ Bidegain, La Organización de Movimientos, 65.
} 
Vargas saw in the Church a fundamental piece of both the new Brazil he was building and the balance of power that maintained him 15 years in power. ${ }^{37} \mathrm{He}$ stimulated the expansion and influence of the Church in education, beneficence and public administration, and obtained in the process ideological legitimation. The Church, in turn, not only expanded its reach to the lowest segments of the population but also participated in the decision-making process in public affairs.

Dom Leme had authorized, in 1932, the creation of the Catholic Electoral League (Liga Eleitoral Católica, LEC), a pressure group with enormous power, through which the Church influenced the election of sympathetic candidates and thus the promulgation of laws that favored the position of the Church and its values. ${ }^{38}$ The LEC and the female Catholic organizations had enormous influence in the redaction of the Constitution of 1934:

Spiritual assistance was allowed in official and military establishments. The religious marriage was entirely recognized in the same terms as the civil and divorce was prohibited. The most important thing for the Church was the constitutional recognition of the religious education in public schools and the economic subvention by the state to the Catholic schools. ${ }^{39}$

Dom Leme, on the other hand, had direct influence on Vargas. The bishop was particularly influential in the government's decision not to establish diplomatic relations with the Soviet Union as well as in the state attempts not to grant recognition to the

\footnotetext{
${ }^{37}$ José Casanova, Public Religions in the Modern World (Chicago: University of Chicago Press, 1994), 118.

${ }^{38}$ Bidegain, La Organización de Movimientos, 75-76.

${ }^{39}$ Ibid., 79. My translation.
} 
divorce law imbedded in the Constitution of $1937 .^{40}$ That charter was the Estado Novo legal framework: the 1937-1945 period during which Vargas strengthened his authoritarian power and carried out most of his ambitious reforms; during that time, the Church-state marriage kept bearing fruits for both institutions.

Meanwhile, as Catholic Action grew, its connections with European and North American lay experiences strengthened. In the decade of the 1940s, Canadian priests and young lay Catholics themselves brought to Brazil the French model of Catholic Action. The French tradition, a truly modern way of lay apostolate in content and organization, gradually permeated and redefined Brazilian Catholic Action. ${ }^{41}$ The starting point of the French model had been the Young Catholic Workers movement, founded by the Belgian priest Joseph Cardijn in $1912 .^{42}$

Cardijn's method of Catholic Action was called "revision of life." It is constituted by three steps in the relation between individuals and reality: see, judge and act. With this perspective, and in sharp contrast with traditional theology, Cardijn stimulated the young workers to think critically. Later on, movements of this kind flourished in universities and high schools, particularly in France and Canada.

In no other Latin American country did Catholic Action expand and grow as much as in Brazil. The movement thrived, with particular power in universities

\footnotetext{
${ }^{40}$ Bruneau, The Political Transformation, 42.

${ }^{41}$ José Oscar Beozzo, Cristãos na Universidade e na Política: História da JUC e da AP (Petrópolis: Vozes, 1984), 35.

${ }^{42}$ Ana Maria Bidegain, From Catholic Action to Liberation Theology: The historical process of the laity in Latin America in the twentieth century (Notre Dame, IN.: Helen Kellogg Institute for International Studies, University of Notre Dame, 1985), 6.
} 
(Juventude Universitária Católica, JUC), factories (Juventude Operária Católica, JOC) and secondary schools (Juventude Estudantil Católica, JEC). Through those organizations an entire generation of young Catholic Brazilians developed a modern way to live their religiosity, acquired skills in organization, and became aware of the deep social problems of their society.

An important condition for that was, again, the lack of native clerics because of which the Brazilian Church had to rely on foreign clergy. There was a constant flow of priests, chiefly from Canada, France, Belgium and the United States. They, and the young Catholics who traveled to attend the international meetings of their organizations, kept Brazilian Catholicism in pace with the latest developments, in praxis and thought, of the European churches.

Even the Dom Vital Center, once the fortress of the most conservative Catholic thought, helped in the development of the new Church that Catholic Action was creating. Its founder, Jackson de Figuereido, had died prematurely in 1928 and the Center was left in the charge of the intellectual and leader, Alceu Amoroso Lima. Under Alceu, the Dom Vital Center became a network that spread the French Catholic humanism of thinkers like Jacques Maritain, Emmanuel Mounier, Ives Congar, and others. ${ }^{43}$

In 1945, as the liberal states emerged triumphant from the defeat over fascism in World War II, Brazil moved towards democracy. Then the restless opposition to Vargas strengthened enough to put an end to the Estado Novo. In the almost 20 years of democratic governments that followed, Brazil continued through the path of development

\footnotetext{
${ }^{43}$ Gómez de Souza, A JUC, 59.
} 
and compromise among the different parties. The marriage of convenience with the Church remained unaltered.

The 1950s would be marked by the revitalization of the national consciousness pushed by the turn of the economy towards oil. During his last term as president (19511954), Getúlio Vargas propelled a movement for the defense of Brazilian resources that ended up with the foundation in 1953 of Petrobras, currently one of the major exploiters of oil in the world. The motto "the oil is ours" (o petróleo é nosso) helped to strengthen the national spirit in Brazil.

Dom Leme's death in 1942 had left a vacuum in the ecclesiastical leadership. A young and always intrepid Hélder Câmara, as priest first and bishop after, took on his shoulders the responsibility for organizing the dioceses under an institutional entity with national scope that gave cohesion to the Church. He was vicar of Catholic Action and had contributed to the creation of the National Secretariat of the movement in the 1940s, at the time the only organization within the Church with a national structure.

Hélder gathered the skills of some female lay elements from Catholic Action and gained the support of Rome to create the National Conference of Brazilian Bishops (Conferência Nacional de Bispos do Brasil, CNBB) in $1952 ;^{44}$ it was the beginning of a truly national Catholic Church in Brazil. As a national institution unified at the top by the $\mathrm{CNBB}$, the Church reached its moment of major expansion and prominence in public life. The governments recognized the power of the bishops, the Catholic press and

\footnotetext{
${ }^{44}$ David Regan, Why are They Poor?: Helder Camara in pastoral perspective (Münster: Lit., 2002), 71.
} 
intellectuals maintained a national audience, and Catholic Action had a leading role in the social movement in schools, factories, and universities. ${ }^{45}$

Catholic Action was definitive for the Church in other ways. Visionary men and women, young workers, students and peasants were having considerable influence with the clergy at least since the $1940 \mathrm{~s} .{ }^{46}$ By the 1950 s some of those priests who had been close to the youth became bishops. Such is the case of Hélder Câmara. He had even militated in the integralismo in the 1930s decade but by the 1940s had gotten deeply involved with the Catholic Youth Workers and radically changed his political standpoint. Dom Hélder, and other bishops like Dom José Tavora, Dom Fernando Gomes, Dom Cândido Padim, and many others particularly from the Northeastern dioceses, became the leadership of the progressive wing of the Church. ${ }^{47}$

Several factors contributed to the success of the Catholic progressive ideas in the Northeast. During the nineteenth and twentieth century, as the southern regions industrialized and urbanized, the Northeast suffered stagnation and even impoverishment. In this region with the highest concentration of the land, the class abyss was more profound than in the rest of the country. Therefore, the Christian inclination for the poor faced in the Northeast an outrageous reality of social justice that looked like a bomb about to explode.

\footnotetext{
${ }^{45}$ Gómez de Souza, $A$ JUC, 64-66.

${ }^{46}$ Mainwaring, The Catholic Church, 73.

${ }^{47}$ Gómez de Souza, $A$ JUC, 64-66.
} 
Having young and able bishops in the higher levels of the Church contributed to the growth of progressive Christianity. Dom Hélder, for instance, was secretary of the CNBB for several years, beginning with its foundation. The progressive bishops, well respected and connected, maintained their influence in the state and used it to make their dreams of social change real. Probably the most notorious case of the time was the Movement for Basic Education (Movimento de Educação de Base, MEB), created in 1961 by bishop Dom José Tavora.

Dom Tavora drew on a literacy program conceived by bishop Dom Eugênio de Araújo Sales in 1958 and gave it a new stronger spirit. The MEB, driven by the Church in the Northeast and supported by the state, proved to be a highly successful literacy program. Given that in Brazil the illiterate were not allowed to vote, with this program the Church had an enormous impact in Brazilian politics and particularly in the Northeastern. The MEB is an extraordinary example of the good relations of the progressive wing of the Church and the reformist leaders of the 1950s and 1960s decades, especially those of Jânio Quadros (1961) and João Goulart (1961-1964).

Although the progressive movement was the most important aspect of the Church in the mid-twentieth century, Brazilian Catholicism still was the sum and contradiction of several standpoints. The inner currents of the Church have usually been divided in progressives, moderates and conservatives or traditionalists. The classification usually depended on the approach to lay pastoral and the commitment to social issues. The inner currents, in turn, were in agreement with a multiplicity of political options that reflected 
national trends. Some churchmen and lay people, for instance, opted for Christian democracy and liberalism.

The Catholic right, on the other hand, was a very strong sector with deep roots in the history of the Church. Meantime, the Catholic traditionalists, corporatists and integralistas had established important alliances with the military and other reactionary sectors that shared their worldviews; the result of that convergence was the creation of the extreme-right movement Tradition, Family and Property (Tradição, Família e Propriedade, TFP). ${ }^{48}$

\section{Historical Context of the 1960s Decade}

Such was the situation of the Brazilian Catholic Church by the end of the 1950s. The 1960s would be years of deep transformations and unrest around the globe. African decolonization, revolutionary outbreaks in several countries, emergence of diverse subcultures in the West and the expansion and diversification of different ideologies of liberation marked the 1960s. In the U.S. and Europe, the Civil Rights movement, the opposition to the Vietnam War and the events of May-68 incorporated long-ignored demands of gender, racial and ethnic equality.

Meanwhile, Latin America accelerated industrialization, expanded other spheres of production and increased its participation in the international fluxes of capital. Economic growth not only increased the capacity of the elites to rule but helped to raise an urban middle class, everyday more ambitious and educated. As production and

${ }^{48}$ Gómez de Souza, $A J U C, 66$. 
consumerism elevated and globalization consolidated, Latin American culture underwent considerable modifications.

Capitalism, through the expansion of cinema, TV and mass media, altered the conceptions of time and space and captivated the anguishes and desires of the entire society. Along with an increasing sense of connection to the world and the growth of urban cosmopolitan cultures, preexistent identities got enforced. Nationalism, for instance, gained new relevance and ideologies of right and left took good advantage of it.

Nevertheless, development, as understood by the U.S. and the Latin American elites, did not mean equality. Huge numbers of the poor population, in search of new opportunities, moved to the cities only to end up crowding into the shantytowns of México City, Buenos Aires and São Paulo. For them there was no economic growth, but impoverishment and new ways of exploitation. The young Catholic students and the most committed progressives within the Church were particularly shocked by this reality.

Everything was set for the reinvigoration of a revolutionary movement of liberation in Latin America. Liberation movements are cultural currents composed by a myriad of traditions, ideologies and even artistic trends that, depending on the historical conditions, increase and decrease with the years. In some way, the movement of the 1960s was the coming to a new state of consciousness. Converging in that consciousness were identities of class and nation, changes in the conceptions of history, new levels of creativity, an increased disposition to social organization and cohesion among other elements. The fundamental component of the movement in the 1960s decade was the self-recognition of some segments of the population as members of a valuable culture, 
their decision to take control of the destiny of that culture and an inclination towards social change.

The spark that ignited the movement and broke in two the history of Latin America was the triumph of the Cuban Revolution in 1959. The success of Fidel Castro and the very existence of a socialist country just 100 miles away from Florida gave hope to a whole generation and reinvigorated the belief that Latin American societies could rule their destinies out from under the shadow of the U.S. From the Rio Grande to La Patagonia flourished diverse movements of young men and women who wanted to free their countries in one way or the other from their dependence on the U.S. Cuba joined the Soviet Union and to a lesser extent China as ideological and, at times, logistical supporter of liberationist and revolutionary movements.

Obviously those who got to the revolutionary and liberationist level of consciousness were those in the higher levels of education. Although still restricted to a privileged minority, by the 1960 s university education was expanding and more people had access to it. Universities had traditionally been spaces of debate and alternative political proposals and in the 1960s students became the most active and politicized segment of the social movement. The importance of the student action was such that they were commonly courted, targeted and even persecuted by governments, parties, the Church and international interests namely American and Soviet.

The student movement had more intellectual resources than ever. In the 1960s, faculties of social sciences and other institutes prospered while structuralism, functionalism and other methodologies consolidated new and complex ways to 
understand society. If one particular theory marked the political and academic debate more than any other, it was Marxism, which by this time was living a moment of important modifications and expansion. It had been 20 years since the publication of Marx's Grundrisse, which had opened important and fertile debates concerning a humanist Marx; cultural Marxism and other trends were in vogue, some in the theoretical field and others as political narratives.

Marxists and a new generation of intellectuals paid particular attention to the place assigned to Latin America in the international context. The elites that had ruled since the nineteenth century were heirs of the Enlightenment and defenders of the ideals of progress, democracy and the liberal state. Those ideals were in a clear contradiction with the living conditions of the majority. The reformists (gradualists) claimed that this was the consequence of underdevelopment. Latin America was in an early stage of progress and by following the historical steps of Europe and the U.S., it would get to their advanced stage of development. Thus, industrialization and modernization had to be stimulated.

In contrast, in those years a new school of progressive intellectuals embraced the dependency theory that relies so much on the Marxist view. This theory claims the existence of exploitative relations between central and peripheral nations. The dynamics of exploitation required that the latter sell basic raw products at low prices and purchase manufactured goods at high prices. This unbalanced trade relationship ultimately gives 
rise to political domination. ${ }^{49}$ Dependency, therefore, does not only circumscribe the economy. Instead, it is a multiplicity of systemic processes that take place in every aspect of society, determining, for instance, the euro-centrism of nations like Brazil. The generation of the 1960s decade had a precise name for all of this: American imperialism.

From dependency theory it was deduced that true development in Latin America would only be possible once the relations of dependency were broken. In this way, dependency theory, actively represented in Brazil through authors such as Theotonio dos Santos and Ruy Mauro Marini, constituted a challenge to the basis of the liberal states in Latin America and thus to the historical rule of the socioeconomic elites. The theory was central for the movement of liberation in general and for progressive Catholic thought in particular.

I have mentioned that the liberationist and revolutionary movement is a cultural phenomenon that implies much more than politics, and embraces every facet of culture including arts, philosophy and religion. For instance, although the writers of the Latin American literary boom did not usually to refer to the concept of liberation, they were part of that wave of self-recognition and cultural optimism of the 1960 s decade that entailed an unavoidable criticism of American imperialism. What that literary generation had in common with the liberationists was an intense and creative identification with their respective cultures. In their stories the characters and their relations, the landscapes and the narratives as such were expressions of a renewed Latin American spirit.

\footnotetext{
49 Fernando Henrique Cardoso and Enzo Faletto, Dependência e Desenvolvimento na América Latina: Ensaio de intepretação sociológica (Rio de Janeiro: Zahar Editores, 1973), 26-27.
} 


\section{Changes in the Vatican}

Important changes were taking place in the Vatican as well. The same year that Castro triumphed in Cuba, Pope John XXIII called for a Second Vatican Council. The Church had become aware of the need for a substantial reformation of its structures and the spirit of Catholicism. Many churchmen felt that their Church was not able to catch up with the fast and deep transformations of the modern world.

The Council (1962-1965) was the height of the process of modernization and updating called aggiornamento and marked the most critical time for the Church since the time of the protestant schism. It was the opportunity for the progressive sectors of Catholicism to introduce changes in the form, content and spirit of Catholicism. Anachronistic and even mediaeval laws and structures were suppressed and reformed; the religious rites and regulations over clothing, behavior and function of the clergy were updated. In some way, in order to keep the pace of history, the Church had to get rid of too heavy robes.

Furthermore, the Council had an important ecumenical character. The Church resolved to intensify the dialogue with other religions and conceptions of the world. This opened the door to the dialogue with Marxism, something that philosophers like Emmanuel Mounier had already done. Mounier (1905-1950) belonged to the French tradition of Catholic thought that assumed a modern position in social and epistemological issues. Jacques Maritain (1882-1973) is probably the best known of this 
school and his work went in the direction of a Catholic humanism. He was also fundamental for the emergence of a democratic perspective in the Church. ${ }^{50}$

Another conspicuous figure was the Dominican Louis-Joseph Lebret (18971966), who made important contributions to the ethical reflections for the modern world. Lebret, on the basis of Christian ethics, developed a profound criticism of capitalism and neocolonialism. These thinkers were very influential in the mid-twentieth century and were highly appreciated in the circles of Catholic Action. Most of the spirit of their thought was captured in the documents of the Council and encyclicals like Populorum Progressio (1967).

Behind-the-scenes of the Council, in informal meetings, Dom Hélder Câmara played an important role in strengthening the ties among social-minded bishops and gaining important spaces for the most progressive wing. ${ }^{51}$ Eventually, the Council provided ideological legitimation to Catholic Action and the growing progressive Christianity in Brazil. Bishops, priests and missionaries were encouraged to adopt the Catholic Action methodology on the Latin American reality. What many Christians saw was the undeniable reality of misery and exclusion in their countries. What they judged was that that reality was unchristian. What they did was try to denounce and change that reality.

In Brazil, however, the lay organizations had a sense of urgency for social change that most of the episcopate did not share and this led to a crescendo of disagreement.

\footnotetext{
${ }^{50}$ Bidegain, La Organización de Movimientos, 121.

${ }^{51}$ Regan, Why are they poor?, 89.
} 
Young students lived the contradiction of belonging to the Catholic Church and to the revolutionary and liberationist movement at the same time. ${ }^{52}$ The involvement of Catholic students in politics resulted in the formation of the movement Popular Action (Ação Popular, AP) in 1962 during a congress of the JUC in Belo Horizonte. ${ }^{53}$ The AP was the final logical step of a growing sector of Catholic youth that wanted to move from a religious movement with political implications to a religiously-oriented political movement.

Bishops in other Latin American churches had made consistent efforts, with relative success, to cut off institutional ties with the politicized students. In Brazil the youth had much more power, their structures had become important for the Church and they counted significant support in the clergy and the episcopate itself. Thus in spite of significant controversies with the most conservative wings of the Church, Catholic Action in Brazil continued. ${ }^{54}$

However, a powerful enemy of the progressive churchmen was taking shape in the shadows. When the reaction came in 1964 in the form of a coup d'état, the repressive apparatus would make the Church pay a high prize for its connections with the students and the nationalist and reformist governments of Kubitschek, Quadros and Goulart (1956-1964).

\footnotetext{
${ }^{52}$ Beozzo, Cristãos na Universidade, 96.

${ }^{53}$ Antoine, Church and Power, 35.

${ }^{54}$ Gómez de Souza, A JUC, 189-197.
} 


\section{United States and Dictatorship}

At least since the times of the formulation of the Monroe Doctrine in 1823, the United States arrogated the right to intervene in Latin American and the Caribbean at will. Military and economic supremacy in the rest of the continent was seen as a condition sine qua non to fulfill the promise of American manifest destiny. During the nineteenth century the U.S. consolidated its power, mainly in Mexico, Central America and the Greater Antilles. Little by little, the British Empire lost its commercial supremacy in the rest of the continent to the United States.

American interests in Latin America had since the nineteenth century permeated every level of the economy, from mining and the cultivation of bananas to banking, financial services and technology. In order to protect its capital and investments, U.S. governments have resorted very often to force, and a myriad of other tactics in violation of international conventions. The U.S. has suborned, blackmailed, sabotaged and intimidated those governments and leaders that do not submit to its interests. When these tactics do not work, the U.S .participates in murdering plots and armed uprisings that end up with dictatorships human rights violations. On no few occasions the United States has drawn on the supremacy of its naval fleet and army to punish societies and governments that dare to oppose it.

Some of the most memorable U.S. interventions have been the invasion of Mexico in 1846 that resulted in the dismemberment of more than $50 \%$ of the Mexican territory, the bombing and destruction of San Juan del Norte Port in Nicaragua in 1854, 
the occupation of Cuba and Puerto Rico in 1898, of Honduras in 1924, and countless incursions into Panamá, Nicaragua, the Dominican Republic and others.

Moreover, the United States emerged from World War II as a consolidated global power and, in the years that followed, it achieved a considerable expansion of its capacity for coercion in Latin America. Nevertheless, with the triumph of the Cuban Revolution, anti-American sentiment extended all over Latin America. As the U.S. felt its hegemony challenged, its militarist policy in the continent hardened. ${ }^{55}$

Even today analysts keep explaining the U.S.-Latin American relations of the post-WWII era as framed and determined by the Cold War. In my opinion, this is a misleading approach. By Cold War I understand the conflictive and dangerous conditions of the bilateral relations between United States and the Soviet Union from the 1940s to the 1980s. As part of the confrontation both nations indirectly disputed regions of influence in the so-called third world. Such are the cases of Korea, Vietnam and Afghanistan.

However, Latin America, far away from Russia, remained a North American fortress; the U.S.S.R. never really had the potential to snatch any part of the U.S. backyard. The Soviet intervention was limited to economic and intellectual support for a few guerrilla groups and communist parties that never constituted a significant threat to the liberal states. The real menace to the American hegemony in Latin America was the growing articulation of demands for self-determination in the context of the Cuban Revolution. In Latin America, "Cold War" was an ideological construct of the American

\footnotetext{
${ }^{55}$ Jerry Dávila, Dictatorship in South America (Malden, Ma.: Wiley-Blackwell, 2013), 15-16.
} 
establishment to create an atmosphere of fear, prone to the spread of the National Security Doctrine, a militarist ideology originated by the French occupation in Algeria.

The American version of the Doctrine was the belief in a Cuban, Russian and/or Chinese conspiracy to politically unsettle the region and institute communist rule. Those who claimed to know the problem also asserted to have the solution. The doctrine held that the communists would take over Latin America by brain-washing the people, particularly the youth, with communist ideology. This implied the existence of an internal enemy in universities, factories, countries and families. Western civilization had to fight them. $^{56}$

The new era of North American intervention in Latin America began in 1946 with the foundation in Panamá of the School of the Americas. ${ }^{57}$ In the years that followed, thousands of Latin American military officials went to the School to learn how to fight the internal enemy. Torture, murder, disappearance of people and other techniques of terror were some of the pedagogic content of the School through the years. ${ }^{58}$ The first intervention completely driven under the doctrine was in Guatemala in 1954 where the U.S. deposed the democratically elected government of Jacobo Árbens, igniting half a century of horror that had its culmination in the indigenous genocide of the1980s.

\footnotetext{
${ }^{56}$ Lars Schoultz, Human Rights and United States Policy toward Latin America (Princeton: Princeton University Press, 1981), 217-221.

${ }^{57}$ Lesley Gill, The School of the Americas (Durham, NC. and London: Duke University Press, 2004$), 26$.

58 U.S. Army and CIA interrogation manuals circulate freely in the cyberspace. See: "Kubark Counterintelligence Interrogation," National Security Archive - George Washington University, last modified February 9, 2014, http://www2.gwu.edu/ nsarchiv/NSAEBB/NSAEBB27/docs/doc01.pdf
} 
Between the 1960s and the 1980s a series of fundamentalist and authoritarian dictatorships, backed and supported by the CIA and U.S. governments, were imposed in several Latin American countries. These military regimes established censorship, abolished and coopted democratic institutions, persecuted labor and student unions, leaders of liberal and leftist tendencies, the intellectual elites of the time and anyone who dared to oppose them; all in all they implemented what they had learnt in the School of the Americas. They also imposed reforms that served the interests of the foreign capital and the economic elites. ${ }^{59}$

The Brazilian military were particularly pro-American. Of all the Latin American countries, Brazil was the only one that had made a serious effort to participate actively in World War II. ${ }^{60}$ The Brazilian troops that battled in Italy in 1944 were trained by U.S. officials and were greatly impressed by American organizational and technological advances. Many of the leaders of the coup of 1964, including Generals Golbery de Couto e Silva and Castelo Branco, belonged to that generation and had been in touch with the American military since then.

The Higher War College (Escola Superior de Guerra, ESG) was created in 1949 in an effort to modernize and systematize the military education following the American models and ideology ${ }^{61}$ In a few years the ESG became the intellectual and political node of the Brazilian military. It was a space for the military to discuss and develop their

\footnotetext{
59 Naomi Klein, The Shock Doctrine: The rise of disaster capitalism (New York: Metropolitan Books/Henry Holt, 2007), 156.

${ }^{60}$ Burns, A History of Brazil, 359.

${ }^{61}$ Lernoux, Cry of the People, 162.
} 
institutional positions regarding the future of the country. Since the ESG also provided education to civilians, it helped the military to create close links with businessmen, politicians and journalists and spread the National Security Doctrine. ${ }^{62}$ With the triumph of the Cuban Revolution those links strengthened and became a political block that counted on the support of the United States.

In August of 1961 the extreme right demonstrated its capacity for action by creating a political crisis that led to the resignation of president Jânio Quadros. They wanted to go further and impede the accession of Vice-president João Goulart but were contained by the democratic reaction of the people on the streets. ${ }^{63}$ The nationalist and reformist Quadros and Goulart were accused of populism and proximity to Marxism. Their protectionist policies in economy, social reforms, reluctance to submit to the American isolationist policy for Cuba and good relations with the social movement were the target of bitter criticisms. ${ }^{64}$

Far-right politics had important links within the Catholic Church, an institution with a long anti-communist tradition. Even the progressive bishops who opened the Church to the dialogue with Marxism were afraid of the red menace. Communism was seen as a dehumanizing ideology that wanted to liquidate family and impose a totalitarian order where faith would be seen as nothing more than "opium of the people." The

\footnotetext{
${ }^{62}$ René Dreifuss, 1964, a Conquista do Estado: Ação politica, poder e golpe de classe (Petrópolis: Vozes, 1981), 80 .

${ }^{63}$ Burns, A History of Brazil, 431.

${ }^{64}$ Quadros was protectionist and had even dared to decorate Che Guevara (then minister of economy in Cuba). Goulart had carried out protectionist policies. A few days before the coup in March of 1964 he had decreed the nationalization of the oil refineries.
} 
persecution of Catholicism in the U.S.S.R. added no little component of fear to this perception. In sum, communism was the negation of the most cherished Christian principles.

In 1960 the most conservative Catholic sectors created Tradição, Família e Propriedade (TFP) that was led by Professor Plinio Correa de Oliveira, bishops Dom Sigaud, Dom Castro Mayer and others. TFP had much of its support in the south of the country, among the traditional elites of São Paulo, and the political circles associated to the ESG, from which it received enormous financial help. ${ }^{65}$

This ultraconservative movement began a campaign of incendiary declarations and mobilizations in defense of western Christian civilization and against the danger of communism. As political polarization deepened, Manichaeism flourished and Brazil got immersed in a discursive spiral of violence. Politicians like Carlos Lacerda, bishops like Dom Jaime Barros Câmara, and tendentious journalists preached the red danger. Terms like "Marxist" and "terrorist," emptied of content, were used to discredit the smallest suggestion of social change. The campaign of destabilization gained support for an authoritarian regime, weakened the government and set the conditions for the coup d'état.

The U.S. participation in the coup of March-April of 1964 has been sufficiently documented. In the last decade, declassification of audio tapes of the White House and cables of the Department of State have brought to public light what had been a wellknown secret for years. ${ }^{66}$ The Johnson administration had inherited from Kennedy a

\footnotetext{
${ }^{65}$ Bruneau, The Political Transformation, 227.

66 "Brazil Marks 40th Anniversary of Military Coup."
} 
profound animosity towards the government of Goulart and was more than ready to support an antidemocratic change of regime. In the days prior to the coup, the U.S. government, at the request of the ambassador in Brazil, Lincoln Gordon, decided to fully support the military revolution. During the critical moments, Johnson's government commanded the shipment of a naval task force, arms, ammunition and petroleum to support the military. ${ }^{67}$

Right after the coup, the U.S., faced with the problem of being aligned with an overtly authoritarian government, began a policy of comprehensive paternalism that lasted for more than one decade. Ambassador Gordon repeatedly showed himself concerned with the "excesses" of the military but continued advocating for economic help to the regime. In the first two years of dictatorship, the United States loaned around $\$ 450$ million to the Brazilian government and maintained a policy of public silence in regards to political repression. ${ }^{68}$

As a corollary to this historical contextualization, I would like talk briefly about the chiefs of the Foreign Service in Brazil during the time that concern this research. Ambassador Gordon, who was in office between 1961 and 1966, had an outstanding diplomatic career and became Assistant Secretary of State for Inter-American affairs right after leaving Brazil. His academic career was no less remarkable; he taught international economic relations in Harvard and was president of Johns Hopkins University between 1967 and 1971. The presence of a diplomat of Gordon's status points

\footnotetext{
${ }^{67}$ See appendix 1.

68 "Foreign Relations, 1964-1968, Volume XXXI, South and Central America; Mexico," Office of the Historian - U.S. Department of State Archive, last modified February 9, 2014, http://20012009.state.gov/r/pa/ho/frus/johnsonlb/xxxi/36365.htm
} 
to the strategic significance of Brazil for the United States during the decisive aftermath of the Cuban Revolution. ${ }^{69}$ In the same way, in comparison to the coming years, the American presence and interference in public affairs was most vehement during the service of Ambassador Gordon. ${ }^{70}$ Gordon was replaced in 1966 by John W. Tuthill, still an outstanding diplomat, though his career was modest in comparison to Gordon's. Charles Burke Elbrick replaced Tuthill in March of 1969 under the Nixon administration. The last ambassador to Brazil for the time of this research was William Manning Rountree who took possession in November of 1970.

\footnotetext{
${ }^{69}$ Green, We Cannot Remain Silent, 24.

${ }^{70}$ Ibid., 74.
} 


\section{CHAPTER 4}

\section{Determinants of the American Interest}

The 167 cables of the Foreign Service in Brazil are irregular during the 19641972 years. Still, they follow a pattern that helps in understanding the basic determinants of the American interest in the Brazilian Catholic Church. ${ }^{71}$ The periods with a higher frequency of cables related to the Church coincide with periods of increasing relevance of the Church or its members in the civil realm.

A rise of the relevance, in the short term, was expressed in declarations, statements, public letters and meetings in which the Church or its members expressed changes or reaffirmations in their positions. Most of the time, those discursive performances had the government as the clear interlocutor and not a few times were a reaction against symbolic or real acts of violence against the Church. These acts of violence were also determinants, though secondarily, of the American interests, and consisted, in general, of arrests, expulsions of foreign priests, torture, raids and accusations of subversion among others. Concomitant with that interest in the Church's relation with the public realm, there was an interest in the internal affairs of the Church, the changes in its internal balance of power, and its relations with other sectors of the society, such as students.

\footnotetext{
${ }^{71}$ See appendix 2.
} 
The gaps and periods of low circulation of cables cannot be simply explained as decreases in the relevance of the Church. Certainly, during the periods in which the Church-state conflict abated, the frequency of the cables lowered considerably. But there exists significant periods of total Church cable absence in circumstances when important events were taking place. How to explain, for instance, the absence of cables between September of 1966 and February of 1968? During that eighteen months long period, Dom Hélder made sympathetic declarations towards Cuba, the military arrested eleven Benedictine monks for helping the students of the UNE to have their XXIX congress and Dom Waldyr Calheiros, bishop of Volta Redonda, started his struggle for human rights, which would eventually make him a frequent target of military repression. ${ }^{72}$

It has to be taken into account that during those years, there were other political conflicts that included unions, students, parties and different levels of the government in which the Church was not involved. Those events and crisis would momentarily distract the attention of the American officials from the Church. In history, even the silence speaks. The U.S. interest in the Brazilian Church is not only informed by what the cables say but also by what they do not. Some meaningful elements about those silences will gradually appear along these pages. Yet, bearing in mind the multiplicity of the factors that could help to explain the absence of information in the cables about specific events, a generalizing explanation in this regards would be too risky. Finally, there is still an important number of classified cables as well as information in other collections to which

\footnotetext{
${ }^{72}$ The National Union of Students (União Nacional dos Estudantes, UNE) gathered the different sectors of the student movement. By this time, the Christian Youth movement was the most important force within the Union.
} 
we did not have access; such is the case of the archives of the CIA and other classified documents.

\section{The Dangerous Church}

I have pointed out in the previous chapter that the Doctrine of National Security and the Cuban Revolution had produced an atmosphere of political polarization during the first half of the 1960s. In Brazil, the progressive wing of the Catholic Church was commonly accused of political radicalism and proximity to "dangerous" groups. ${ }^{73}$ Accusations centered on the leaders of the Movement for Basic Education, foreign priests, and progressive bishops like Dom Hélder Câmara, but particularly on student organizations and clergymen involved or supportive with them.

In the same way, the concerns of the U.S. diplomatic mission in Brazil went along the lines of McCarthyism. A cable of January 3 of 1964 from Rio de Janeiro with copy to the embassy in Rome reported the spread, during the previous month, of a draft letter in which the CNBB strongly warned Catholic Action and its secretary bishop, Dom Cândido Padim, of any involvement in politics, and condemned any deviation from Christian dogma. It was one more try of the Catholic hierarchy to distance the Catholic University Youth from the Popular Action (AP) which did not represent the "authentic Christian thought." 74

\footnotetext{
${ }^{73}$ Antoine, Church and Power, 26.

74 Report, Rio de Janeiro, January 3, 1964, State Department Cables, U.S. Embassy, Brasilia, National Archives, box 5.
} 
The cable celebrates that the Church "has decided that cooperation with the Marxist, theoretically non-Communist Popular Action is more likely to aid Communism than the Church."75 The comment contains some elements that characterized the American view on the Church during those years. National Security Doctrine combines a paternalistic discourse that negates the moral agency of most of the people and a Manichean view of the world as ultimately divided between communism and evil on one hand and capitalist democracy and goodness on the other. The Church is regarded, in a broad sense, as a naïve institution and a vehicle of communists, extremists or terrorists who are malicious enough to deceive and manipulate unwary people to their own ends. In this way, the old uneducated bishops, the young and pious priests would almost unconsciously be makers of the national debacle in Brazil. Therefore, the Church was suspicious.

The National Security Doctrine had similar understandings of the students. They, young and inexperienced, were as easy prey as the priests for the machinations of the obscure forces of communism and terrorism. Here, communism and terrorism were abstractions that played the role of the enemy in the discursive war. In the real war, which used electric shocks and the Nazi tactics of night and fog, the enemies were students, priests and other organic parts of society that would not easily be targeted in the discourse without causing mental resistance in the majority of the people. This linguistic strategy transformed the most progressive sectors of society into dupes at the service of

\footnotetext{
75 Ibid. It is worth noting that the AP, though it was called "communist" and "extremist," was a Christian movement that never resorted to violence.
} 
hidden forces. A concomitant linguistic step transformed the naïve dupes into dangerous suspects. In the dirty war of the 1960s and 1970s, "suspect" usually meant guilty.

Another cable of January of 1964 expands the information of the first in regards to the connections of the Church with the AP. In this communication, Robert Dean, counselor of the embassy, recognizes the role of the Church in the modernization of Brazil and points out that some of its elements support and participate in the "negative left.. ${ }^{76}$ Dean depicts the MBE as subverted by extremists and repeats the words of Brazilian intellectual Erico Verissimo, for whom the National Union of Students (UNE) is "an alliance of the Church with the Communists." ${ }^{, 77}$ Farther on in the same text, Dean expresses concern that the draft letter that condemns the AP would not have the approval of the majority in the Church because of internal divisions.

The U.S. was attentive to the Church's reception of the military regime from the very beginning. 26 members of the CNBB met on May 27 of 1964 to have a two day long discussion on the Church's position in regards to the coup. An official statement was released on June 2. In the declaration, the bishops expressed gratitude and praised the military for their heroic role in the struggle against communism. Furthermore, the episcopate made a mea culpa in which recognized the presence in its lines of "victims of their own idealism." The bishops were referring directly to the most progressive sectors of the Church in the same paternalistic way of National Security.

\footnotetext{
${ }^{76}$ Report, Brasilia, January 15, 1964, State Department Cables, U.S. Embassy, Brasilia, National Archives, box 5 .

${ }^{77}$ Ibid.
} 
Nonetheless, at the same time the episcopate expressed uneasiness for the already evident hostilities against the Church and rejected the generalizing accusations of communism against Catholic Action and the MEB. Farther on, the bishops made statements of support for democracy, dialogue and other generalities. One week later in a cable, the most independent and critical parts of the episcopal document were observed with irony: "The bishops also chose to lecture the revolutionary leaders on the urgent need for reforms based on "the social doctrine of the church".,"78

The cable also highlights the agreement between the contrasted currents inside the Church, pointing out that for the first time in recent history the progressive Dom Hélder and the conservative Dom Jaime de Barros Câmara together signed an episcopal document. ${ }^{79}$ For Charles Antoine, the declaration of June 2 was the consequence of a "laborious compromise" between supporters of the regime and defenders of social justice. ${ }^{80}$ The plurality of the opinions present in the document, on the other hand, may have counted for the wide support it received in the episcopate.

After the coup, the military unleashed a political repression directed mostly at political institutions, universities and the Church. ${ }^{81}$ The repression was carried out through public accusations, detentions, raids, intimidations etc. Within the Church, the

\footnotetext{
${ }^{78}$ Report, Brasilia, June 10, 1964, State Department Cables, U.S. Embassy, Brasilia, National Archives, box 5 .

${ }^{79}$ Ibid.

${ }^{80}$ Antoine, Church and Power, 29.

${ }^{81}$ The repression against universities all over Brazil was one big tragedy for Brazilian culture. The rage against the academic milieu was such that the intellectual Alceu Amoroso Lima talked of "cultural terrorism." See: Serbin, Secret Dialogues, 74.
} 
MEB and the Catholic University Youth, the most progressive structures, were the most affected. Since the MEB was dependent on the support of the state, by removing the institutional support the military were able to weaken it badly. It would require more energy and time from the repressive apparatus to affect the Catholic students.

Four months after the coup, the Foreign Service reported about a document entitled "Misery in Latin America: Fate or wrong-doing?" This document, issued by the Catholic students and directed to the priests meeting in the Vatican Council, was catalogued by the U.S. officers as "nationalist and anti-American propaganda." The document, which dealt with economic and social problems of the time, contained dangerous postures: "The falling prices of raw materials, the rise in cost of manufactured goods, U.S.-tied procurement - all the old and often-disproved charges - are used as points of attack on the U.S. for "economic injustice"." The silence of the social movement after the first wave of military repression had not lasted too long; now, the American officers were setting off alarms about the reappearance and reorganization of "leftist Catholic groups" that were becoming "vocal" and "dangerous" again. ${ }^{82}$

During those first days of August of 1964, Ambassador Gordon paid a courtesy call on the recently appointed Papal Nuncio, Sebastiano Baggio. Gordon expressed special interest in the positions the Nuncio would take in regards to the student movement, Catholic Rural Unionism and the MEB. If the call had the purpose of assessing the proclivity of the new Nuncio to help the American interests, the results were ambiguous. The Nuncio indicated "keen interest in the idea of cooperating with the

${ }^{82}$ Report, São Paulo, August 13, 1964, State Department Cables, U.S. Embassy, Brasilia, National Archives, box 5 . 
United States Embassy in both the labor and student fields." Nonetheless, Baggio let the ambassador know that he did not share the Manichean attitude of the military that "were unable to distinguish between serious cases of Communist loyalties and mere progressivism." ${ }^{83}$

The activities of the Catholic Youth were still an important concern for the U.S. diplomatic services more than one year after the coup. On May 18 of 1965, Harold M. Midkiff, U.S. Consul in Salvador, visited bishop Dom Eugênio Araújo Sales in his office. In the subsequent conversation, the bishop talked openly about his policies in the archdiocese and the Consul showed interest in the links of the Church with the AP and the students in general. Midkiff made reference to Dom Jerônimo de Sá Cavalcante of the São Bento Monastery in Salvador who, as a result of his proximity to the student movement of Bahia, was seen with suspicion by the military, a suspicion that was shared with the consulate. ${ }^{84}$

A cable of May 13 of 1965 expounded the life, career and ideas of Dom Jerônimo, who was described as a very progressive man, close to Dom Hélder and with an enormous influence on the youth: "It seems likely that Dom Jerônimo [sic] will have increasing scope for his social reform ideas now that Dom Eugênio Sales has taken over the administration of the Salvador Archdiocese. His influence on young people seems

\footnotetext{
${ }^{83}$ Report of conversation, Rio de Janeiro, August 17, 1964, State Department Cables, U.S. Embassy, Brasilia, National Archives, box 5.

${ }^{84}$ Report of conversation, Salvador, May 21, 1965, State Department Cables, U.S. Embassy, Brasilia, National Archives, box 5.
} 
certain to be a positive force for developing an alightened [sic] Catholic leadership in the Salvador area." 85

\section{The Conflict Begins}

Gradually, as the military unveiled their socioeconomic policies and it became evident that their strength was brute force, a public confrontation between Catholic progressivism and the military arose. The center of the conflict was the Catholic Action, whose members, favorite targets of the repression, were highly critical of the socioeconomic direction of the country. The American cables of the time, though very attentive to the Church-state emerging confrontation and to any criticism towards the regime, did not show the same interest in the political persecution and the authoritarianism of the regime.

A cable of June 29, 1965 reported the release of a "manifesto" by the Worker Catholic Action (Ação Católica Operária, ACO) of São Paulo that denounced the situation of unemployment in that city. A few days later, Cardinal Dom Agnelo Rossi made a statement that "removed much of the ammunition from the hands of those who could have used the ACO manifesto against the government." The cable also reported the arrest and mistreatment of a priest and two students in the town of Goias Velho during a protest: "Although physical punishment [italics added] was employed, there is no

\footnotetext{
${ }^{85}$ Biographic data form, Rio de Janeiro, May 13, 1965, State Department Cables, U.S. Embassy, Brasilia, National Archives, box 5.
} 
evidence of any anti-Church campaign. ${ }^{„ 86}$ Evidently, in the cable the repressive violence is almost disregarded whereas the main concern is the respectability of the regime.

The cable described other skirmishes, suggesting that "leftist press," such as the journal Ultima Hora, had enormous responsibility in stirring up Church-state conflict. The cable criticized Ultima Hora for using words like "torture" and "persecution" in its headlines. For the reporting officer, the "alleged coolness" between the two institutions was little more than a creation of tendentious leftist press. The most remarkable element in the situation was how that alleged conflict was to be used in "anti-government attacks." In sum, the American view of Church-state relations was a total identification with the preoccupations of the regime itself: no real concern for freedom, democracy or the rule of law, but about the political cost to the military regime of a conflict with the Church.

Church-state relations and the activities of the Catholic youth were still the main concern of the U.S. officers by mid-1966. The students, clandestinely organized around the UNE, were re-strengthening politically and demanding the support of the episcopate. Most of the bishops were more focused on maintaining stable relations with the regime and were doing anything possible to cut off institutional ties with the students. But the progressives understood their support to the youth as a duty and were ready to assist them. ${ }^{87}$

\footnotetext{
${ }^{86}$ Report, Rio de Janeiro, June 29, 1965, State Department Cables, U.S. Embassy, Brasilia, National Archives, box 5.

${ }^{87}$ Antoine, Church and Power, 80.
} 
In July, when the UNE had its national congress in Belo Horizonte, the religious orders took measures to protect them from state repression and let the students use the convents to carry on the meeting. Meanwhile, the bishops of the Northeast, headed by Dom Hélder Câmara, gave clear indications of their support to the progressive lay basis by endorsing two documents of the Workers Catholic Action ACO of Recife and the Catholic Agrarian Youth (Juventude Agrária Católica, JAC). The documents consisted of analysis of the socioeconomic situation of the northeastern peasants and workers that implied criticisms of the status quo. The final document, with the approval of the bishops, came to be known as the "Manifesto of the Bishops of the Northeast."

All of this unleashed the rage of the military that intensified its repression and made of bishop Dom Hélder Câmara an object of bitter criticisms and black propaganda. Church-state relations had reached its lowest point thus far. In those days, as the episcopate showed support for the bishop, the high military circles moved towards conciliation. In August, the president, Castelo Branco himself, met with Dom Hélder in Recife and silenced the enemies that the bishop had among the military of the Northeast.

The American diplomatics regarded the protection of the students in Belo Horizonte and the manifesto of the bishops as "examples of the increasing activity of the Church in Brazilian political affairs. ${ }^{\prime 89}$ The lack of historical perspective of the Foreign Service is noteworthy. As was made clear in the previous chapter, the Church had been

\footnotetext{
${ }^{88}$ Ibid., 85.

${ }^{89}$ Report, Rio de Janeiro, August 19, 1966, State Department Cables, U.S. Embassy, Brasilia, National Archives, box 9 .
} 
involved in political affairs for decades. The difference was that by 1966 there was a sector that had adopted a critical distance from the de facto government.

The Church-state conflict was the center of attention for the American Foreign Service in Brazil by mid-1966. ${ }^{90}$ In the U.S. view, the heart of the matter was the attention the conflict had in the media. Furthermore, Dom Hélder and his supporters in the episcopate were depicted as belligerents, who kept the scandal alive with new statements and declarations. The apparent American concern about the press coverage of these conflicts was actually a real concern for the stability of the regime: "What began as a relatively mild protest over conditions in the Northeast has by inept local military action and inadequate defensive measures on the national level been blown up far beyond its real importance. The opposition has naturally made the most of it." ${ }^{\text {,91 }}$

Interestingly enough, American concern for the fate of the regime led the consulate to regard not only the Church but the military themselves as a threat to the regime. During all the period that this study covers, a sort of disenchantment of the Americans with the Brazilian military occasionally surfaces. For the U.S., the Brazilian military were incapable of dealing with certain problems and at times their ineptitude contributed to worsen the conflict. That perception was inherent to the paternalistic character of the National Security Doctrine and other historical relation of the U.S. with the world.

\footnotetext{
${ }^{90}$ See appendices 3 and 4.

91 Report, Rio de Janeiro, August 26, 1966, State Department Cables, U.S. Embassy, Brasilia, National Archives, box 9.
} 


\section{The Church and Students}

During 1968, the coolness and skirmishes of previous years degenerated into open conflict between the Church and state. In consequence, the number of cables grew in comparison to the previous years. Moreover, in 1968 the progressive bishops, particularly the northeasterners, became more critical of the socioeconomic problems of Brazil and opted decisively for protecting the students from the state repression.

If the U.S. officers regarded the Brazilian military as inept, the events of 1968 would prove them right. On March 28, a young student, Edson Luis de Lima Souto, was killed by the military police during a demonstration in Rio de Janeiro. This provoked the indignation of the students, who, with wide support from the masses, started a year of tireless mobilizations that would make the government tremble. The U.S. was attentive to the situation of the students and their links with the Church. ${ }^{92}$ In June of 1968, a cable from the Consulate General in Recife about a "Church-student alliance in the Northeast" read:

There is growing evidence that the Church in the Northeast is moving toward closer identification with student activists. In the past six weeks no less than five leading churchmen have by word and deed demonstrated their support for reform-minded university students. While most of the prelates involved are associated with the "progressive" wing of the Church which has frequently been out of step with the rest of the Church hierarchy, they in this instance at least, are believed to reflect the feelings of a growing cross section of their fellow churchmen. ${ }^{93}$

\footnotetext{
92 Telegram, Rio de Janeiro, April 09, 1968, State Department Cables, U.S. Embassy, Brasilia, National Archives, box 24.

${ }^{93}$ Report, Recife, June 7, 1968, State Department Cables, U.S. Embassy, Brasilia, National Archives, box 24 .
} 
Certainly, the Church of the Northeast strongly supported the students; Dom Antonio Batista Fragoso, Dom Hélder, Dom Fernando Gomes, and Dom José Medeiros Delgado had moved vehemently in that direction. As a result of the progressive inclinations of the Northeastern bishops, they were usually objects of keen observation by the American diplomats. It is worth noting the perception of growing unity in the Church that the U.S. had by 1968 as a result of the support for the students.

Had such unity truly been the case, it would very soon be called into question. On June 10, the Recife city councilman Wandenkolk Wanderley, probably the most fervent opponent of Dom Hélder Câmara in the Northeast, released the contents of a study by the Belgian priest Joseph Comblin, who belonged to the circle of the bishop. The study about the socioeconomic problems of Latin America was meant to be presented in the General Assembly of the Latin American Episcopal Conference (Conferencia Episcopal Latinoamericana, CELAM) to be held in Medellin that August.

The Consulate in Recife regarded the document as subversive and inflammatory for claiming the need for a radical change in the socioeconomic structures of Latin America. Of particular concern were the Comblin's criticisms of the U.S.: "The document, he [Wanderley] pointed out, made no reference to oppression in the Soviet Union and warmly praised the Cuban revolution while criticizing the governments of Portugal, Spain and the United States. In short, Wanderley concluded, the document opposed all those who combat communism." ${ }^{94}$

\footnotetext{
${ }^{94}$ Report, Recife, July 3, 1968, State Department Cables, U.S. Embassy, Brasilia, National Archives, box 24.
} 
Furthermore, the cable described the controversy ignited in the press by the document and judged that the support for Dom Hélder in public opinion had been seriously affected. However, at the same time, the cable acknowledges that "Most responsible Northeasterners have fortunately learned to discount attacks upon Dom Hélder from the likes of Wanderley and his colleagues. ${ }^{" 95}$ Some weeks later, as Tradição, Familia e Propriedade attacked Dom Hélder, a cable from the Consulate in Recife maintained that the ultra-right group attracted people of the sort of Wanderley, who was discredited in public opinion for his "almost pathological attacks" against the bishop. ${ }^{96}$ This cable shows how, in spite of some proximity, the U.S. services preserved some distance from the traditional right wing of Brazil.

The year of 1968 was key for progressive Catholicism and for the student movement in Brazil. During the conference of the Latin American episcopate in Medellin, the most progressive bishops, led by the Brazilians, were able to give to the Church its most revolutionary push. In the conclusions of Medellin, the bishops used Cardijn's "revision of life" method to understand the Latin American reality and made a commitment for social change. For many observers this was the official birth certificate of the Liberationist Christianity; the progressivist movement was living a moment of hope. Bishops, foreign worker priests and lay people involved in Catholic Action would preach openly the need for social change and requested the participation of the people of

\footnotetext{
${ }^{95}$ Ibid.

${ }^{96}$ Report, Recife, September 5, 1968, State Department Cables, U.S. Embassy, Brasilia, National Archives, box 24 .
} 
God in the process. For most of them, this was not much more than the adaptation of the Vatican Council to the Latin American reality.

On the other hand, besides the indignation over the death of Edson Luis, the student unrest of 1968 contained further implications. Popular mobilizations in many parts of the world were taking place and the revolutionary movements displayed enormous ability to summon the masses. People went massively to the streets in the U.S., Japan, France, Mexico and the Southern Cone, just to mention a few cases. Consequently, the reactionary forces counterattacked with violence; in the U.S., Martin Luther King was assassinated and in Mexico the government perpetrated the Tlatelolco Massacre. In Brazil, the support of an important sector of the Church for the student movement led to a spiral of deterioration in Church-state relations during the second half of the year.

The military regime, stunned by the popular unrest and the loss of support in the remaining political institutions, was moving towards an even more repressive policy. Arrests and persecutions were running continuously, which exacerbated the demands for democracy and social change, ergo: the mobilizations in the streets. The military rage against progressive Catholics was not always able to distinguish the political position of individuals. Therefore, the arrests and accusations of subversion and communism in some instances ended up affecting moderate and even conservative churchmen. The offended bishops, who denounced the persecution and protested the McCarthyism, were gaining the support of most of the hierarchy. Even though they reacted as individuals and leaders of their dioceses, the less lucid of the military saw an enemy in the Church as a whole. 
The repressive apparatus, outraged by the Comblin affair, started targeting a particularly vulnerable sector of the progressive Catholicism: the foreign priests. In November 29, three French Assumptionist priests, a few Brazilian churchmen and lay people were arrested in Belo Horizonte. Until they were set free in February of 1969, the regime continuously threated to expel them. As a consequence of the progressive line of a good part of the foreign clergy, they were a natural target for the military. Moreover, taking into account the Church's dependency on the foreigners, for the bishops a threat to them was a threat to the functioning of the Church itself. The U.S. diplomats assessed that whether the government was to "employ expulsion as a routine device to dispense with foreign ecclesiastics who express public opposition to it," the strategy would produce very different outcomes: ${ }^{97}$

Rather than voluntarily restrain themselves in the face of possible expulsion or intimidation by the Government, or msek [sic] advice from some bishops, there is every reason to project that such foreign progressives would actively seek to challenge to GOB outright with the intention of provoking a Church-State showdown. Should such defiance occur, foreign priests would certainly be supported by liberal activists among the Brazilian clergy, such as the Dominicans who have been in the vanguard of most anti-Government actions by the clergy. ${ }^{98}$

This report calls attention to the fact that, for the U.S., the foreign priests were radicals who deliberately resorted to provocation to foster Church-state crisis. Even more, the consequent and anticipated repression would be opportunistically used to reinforce the opposition to the regime. Again, in the short term, the repressive policy of the military

\footnotetext{
${ }^{97}$ Report, Rio de Janeiro, February 4, 1969, State Department Cables, U.S. Embassy, Brasilia, National Archives, box 33 .

${ }^{98}$ Ibid.
} 
in this regard was not just ineffective but counterproductive; it was a factor producing unity in the Church. Even the conservative Dom Jaime de Barros Câmara had resented the government's threat to summarily expel the Assumptionists. ${ }^{99}$

\section{A Turning Point}

The unceasing student mobilization protected by the progressive Catholics, growing discontent with the government in political circles and ideological polarization were jointly undermining the regime. In the always difficult balance of power among the different factions within the military, the most authoritarian sectors were strengthening. In December 13 of 1968, they forced the Institutional Act Number 5 (Ato Institucional 5, AI5) that initiated the most severe years of repression.

The AI5 dismantled the few remnant political structures that the dictatorship had not dissolved in order to maintain a democratic façade. The military concentrated its power in a small circle, stiffened censorship, prohibited any expression of discontent, restricted civil liberties and gave unprecedented powers to the repressive apparatus. As the regime made a leap towards a state of terror in which torture, murder and disappearance of dissidents became massive, Brazil's hopes for a quick return to democracy faded away. ${ }^{100}$

The AI5 brought some slight variations to the U.S.-Brazil relations. As a matter of fact, although the American position towards Brazilian repression was generally one of complicity, some reservations had never been absent. American diplomats had

\footnotetext{
${ }^{99}$ Ibid.

${ }^{100}$ Moreira Alves, State and Opposition, 95-96.
} 
disdainfully observed the tactlessness of the Brazilian military since the very beginning. ${ }^{101}$ To them, the hardening of the authoritarian character of the regime was also a consequence of the military's ineptitude.

Moreover, the increase of the repressive policies was badly received by the international press. It became increasingly difficult for the U.S. to justify its unconditional support for an intolerant regime that systematically tortured its citizens. ${ }^{102}$ Emergent international networks of opposition to the dictatorship were taking shape. In the U.S., Brazilian exiles, brazilianist scholars, the Catholic Church and American Protestant churches began a campaign of denunciation of the repression and increased pressure in public opinion to make Washington change its policy of complicity.

To complicate the situation, on December 15, two days after the imposition of the AI5, Darrel Rupiper and Peter Grams, two American Oblates linked to Dom Hélder were arrested in Recife. Following the habitual pattern of state persecution, the priests were accused of subversion and faced military trial. With the involvement of the embassy on their behalf, the priests accepted "voluntary expulsion" and left the country by Christmas. During their time in the hands of the military the priests could hear the screams of the tortured prisoners. When they landed back in the U.S., they were a living testimony of the human rights violations in Brazil. ${ }^{103}$

\footnotetext{
${ }^{101}$ Report, Rio de Janeiro, June 29, 1965, State Department Cables, U.S. Embassy, Brasilia, National Archives, box 5 .

${ }^{102}$ Green, We Cannot Remain Silent, 97.

${ }^{103}$ Ibid., 99.
} 
In spite of all, the Brazilian regime was a natural ally of the U.S.; any change in the American attitude towards the military would therefore occur with subtleness: "The tightrope maneuvering that State Department officials recommended entailed discreetly trying to convince sectors of the Brazilian military to moderate their measures so that the political situation would not place the U.S. government in the position of having to distance itself from the regime." ${ }^{104}$ The State Department judged that either distancing itself from the Brazilian military or exerting too much pressure on it would make the military adopt an isolationist nationalist attitude. The visit of Rockefeller to Brazil next June was to be a sign of American support for the Brazilian government.

The progressive Catholics had some hopes for a decisive shift in the U.S. posture. Facing the enormous limitations on free speech in Brazil and the hardening of the repression, the bishops were increasingly resorting to the international community to denounce human rights violations. For obvious reasons, the first likely ally was the Vatican. At the end of January of 1969, during a conversation between Dom José de Medeiros Delgado, archbishop of Fortaleza and the political officer Richard H. Melton, the former stated that the Pope and the Vatican were aware of the situation in Brazil and that they fully supported the Brazilian hierarchy. ${ }^{105}$ As we will see, during the next months and years the Vatican would play an increasingly important role in the Church's defense of human rights in Brazil.

\footnotetext{
${ }^{104}$ Ibid., 95.

105 Report of conversation, Recife, February 4, 1969, State Department Cables, U.S. Embassy, Brasilia, National Archives, box 33.
} 
The bishop made other important comments during that conversation. He basically showed hopes that the United States would speak out against the deepening of the repression and would align on the side of human rights and dignity. Nonetheless, Dom Medeiros seemed aware that any move by the U.S. government would be very subtle. He was probably thinking that any shift in the U.S. policy would be very unlikely under the new administration of Richard Nixon (1969-1974). That was essentially what Cardinal Dom Agnelo Rossi said to the American Consulate of São Paulo in February. Rossi had fewer expectations than Medeiros; he expected from the U.S. only the moderate and friendly advice of a father:

Rossi commented that many Brazilians thought President Nixon's election raised hope in Brazilian military men that U.S. would be more tolerant to authoritarian conservative regimes in Latin America. Some Brazilians even blamed "imperialist" U.S. for inspiring IA-5. In response question Rossi replied USG should express to GOB private concern as friend over events in Brazil and hope country would soon return democratic path. ${ }^{106}$

For the progressive churchmen, the first five years of the dictatorship had produced a government against social change that was also repressive. After the AI5, the regime was mainly regarded as an enormous repressive apparatus. This affected their view of the U.S., which for them, would eventually be no longer the imperialist country that supported the regime but a hopeful landscape with an emergent movement for the defense of human rights whose government could have a real influence in the human rights policy of the dictatorship.

\footnotetext{
106 Telegram, São Paulo, February 24, 1969, State Department Cables, U.S. Embassy, Brasilia, National Archives, box 33.
} 


\section{A Modern Martyrology}

The AI5 was in some ways a coup within the coup, a victory of the authoritarian faction over the moderates of the military. ${ }^{107}$ As in the events of 1964, the U.S. was highly interested in the official position of the Church. As a first reaction, the leaders of the Church had ceased to refer openly to the situation and took the AI5 as a fact with no chance for a quick reversal. Although most of them totally rejected the AI5, their attitude was of openness to dialogue and collaboration with the government. They were giving the government the benefit of the doubt in regards to the AI5. The Diocese of Guanabara, in particular, was striving for dialogue with the government in order to appease the tensions that had been accumulating since 1964 and that exploded in 1968. At the bottom, the U.S. Service read in the attitude of the bishops a pessimistic assessment of the situation and a readiness to oppose the government at any moment. ${ }^{108}$

The Church wanted to be united behind any measure they may take. The previous year had been marked by a relation with the government through individual actions and statements. For the year of 1969, the bishops judged, facing a more authoritarian state, individual opposition would only lead to more repression. The Church's struggle for one institutional posture in regards to the regime would take the remaining years of the 19641972 period. Based on the information the U.S. officers could obtain, they were under the impression that the Church was moving towards a policy of support to those affected by

\footnotetext{
107 See: Moreira Alves, State and Opposition, 95; and Antoine, Church and Power, 205.

108 Report, Rio de Janeiro, January 31, 1969, State Department Cables, U.S. Embassy, Brasilia, National Archives, box 33.
} 
repression but in a very conciliatory way. ${ }^{109}$ A glimpse of the Church's attitude is the comment of a reporting officer after a conversation with the leaders of the Church in Belo Horizonte that, as a result of the case of the French Assumptionists, was in the center of the debate:

Belo [Horizonte] Church leaders regard the Church as the only national institution capable of resisting the government and believe the Church must continue to work for social change in Brazil. At the moment, however, they appear to have decided to play this role in a low-key manner, believing that Church unity would be endangered and popular support lacking if they attempted to actively confront the government in the spheres of political activity. This restraint will end, however, if the government takes repressive measures against the Church or if the government fails to find solutions to pressing national problems. ${ }^{110}$

At the request of the Northeastern bishops who had suffered the heaviest repression, the Central Commission of the CNBB had an extraordinary meeting on February to set its position towards the AI5. ${ }^{111}$ The resulting document resembled the one of May of 1964 in comprising the broad plurality of the Church; it expressed deep concern about the consequences the AI5 would have on the human rights situation of Brazil and regretted the "existing misinterpretation and incomprehension concerning the activities of the Church in our country, even if there has been imprudence-which we

\footnotetext{
${ }^{109}$ Report of conversation, Recife, February 4, 1969, State Department Cables, U.S. Embassy, Brasilia, National Archives, box 33.

${ }^{110}$ Report of conversation, Belo Horizonte, February 13, 1969, State Department Cables, U.S. Embassy, Brasilia, National Archives, box 33 .

111 Telegram, Recife, February 20, 1969, State Department Cables, U.S. Embassy, Brasilia, National Archives, box 33 .
} 
equally regret." ${ }^{\prime 12}$ No less importantly, the bishops also expressed the need for redemocratization "as soon as possible." At the same time, they diplomatically expressed desire to collaborate with the government. ${ }^{113}$ In spite of the different elements of the document and the myriad of likely interpretations, for the U.S., in some respects the CNBB declaration was a truce. ${ }^{114}$

However, the situation in the Northeast was still worrisome. The clergy of that region were particularly reluctant to overlook the social situation; ergo they kept being targeted by military repression. Probably as a consequence of the military control of press and media, the events of the Northeast were treated as a regional problem. One event that did not remain in the Northeastern context but shocked the nation and had international consequences was the torture and murder, on May 26 of 1969, of father Antônio Henrique Pereira da Silva Neto.

The 28 year old priest was the cleric responsible for the Catholic University Youth in Recife and worked very closely with Dom Hélder Câmara. Father Henrique had replaced Luis de Sena and Almery Becerra, two Brazilian priests who had been forced to leave the country as the regime issued death threats against the bishop and anyone who worked with him. After the murder of Henrique, the authorities did their utmost to divert the investigation and distract the public attention. In the communications of the Consulate

\footnotetext{
${ }^{112}$ Report, Rio de Janeiro, March 14, 1969, State Department Cables, U.S. Embassy, Brasilia, National Archives, box 33 .

113 Telegram, Rio de Janeiro, February 25, 1969, State Department Cables, U.S. Embassy, Brasilia, National Archives, box 33.

${ }^{114}$ The bishops' statement was presented to President Costa e Silva on February 21 by Cardinal Dom Jaime de Barros Câmara and Dom Aloísio Lorscheider. Report, Rio de Janeiro, March 14, 1969, State Department Cables, U.S. Embassy, Brasilia, National Archives, box 33.
} 
in Recife about the crime, the U.S. diplomats show an almost nonexistent capacity to distrust the diverting thesis of the authorities that very quickly presented the murder as a crime of passion:

Thus far there is no firm evidence indicating who responsible for murder. Speculation in Church and university circles is that Communist Hunters Command (CHC), right-wing terrorist organization is responsible. Police sources, however, say privately it probably "crime of passion" with no political motivation. Recife press, operating under self-censorship gives scant attention to murder which covered on inside crime pages by short factual account supplied by police. ${ }^{115}$

It is worth noting how in the cable the ideology and alignment with the regime is shrouded with an aura of objectivity. The reporting officer does not only overlook the whole context of persecution and repression but does not show the minimum critical distance from the official version that heavily relied upon strict censorship. Even six months later, when referring to the crime, the American cables would be faithful to the variable official versions that by December suggested the crime had been committed by "degenerate drug users." The Consulate easily dismissed the indications of a political crime as a consequence of "emotional suspicion" of the Church. ${ }^{116}$

For the U.S., the causes of the crime and its connections with a state of terror in Brazil were not as important as its effect on public opinion and the strain it could bring to

\footnotetext{
115 Telegram, Recife, May 28, 1969, State Department Cables, U.S. Embassy, Brasilia, National Archives, box 33 .

116 Report, Recife, December 12, 1969, State Department Cables, U.S. Embassy, Brasilia, National Archives, box 34 .
} 
the Church-state relations. ${ }^{117}$ There was also concern for an intensification of Dom Hélder's denunciations against the government. Two days after the crime, the comment of a telegram read: "Dom Hélder likely to regard incident as consistent with alleged strategy to have him shifted by Church even if military authorities opposed to this sort of terrorist action." 118 As in previous years, the American Foreign Service did not show any interest in freedom, democracy nor the life those who opposed the dictatorship but in the fate and stability of the regime.

The General Assembly of the CNBB in July of 1969 was expected to be a new moment of definition of the Church regarding the political situation of the country. The American officers were very interested in the possible outcomes of the meeting, particularly in the position the Church would adopt in its relation with the government. ${ }^{119}$ The sources of the U.S. officers indicated that the Church would maintain its moderate position.

The replacement of Nuncio Sebastiano Baggio with Umberto Mozzoni in June had been interpreted as a conservative turn in the policy of the Vatican towards Brazil. Baggio had been supportive with the progressives and the Brazilian government would have exercised some pressure in Rome to have him out of the country. Mozzoni, on the

\footnotetext{
117 "Unless there dramatic new developments in case, with passing of seventh day mass, crime may gradually drop from public sight." Telegram, Recife, June 6, 1969, State Department Cables, U.S. Embassy, Brasilia, National Archives, box 33.

118 Telegram, Recife, May 28, 1969, State Department Cables, U.S. Embassy, Brasilia, National Archives, box 33 .

${ }^{119}$ Report of conversation, São Paulo, July 9, 1969, State Department Cables, U.S. Embassy, Brasilia, National Archives, box 33.
} 
other hand, was held as conservative. ${ }^{120}$ Another cable, of July also explored some signals from the Vatican that led the American officers to think that Rome was inclined to counterbalance the power of the Northeastern churchmen. ${ }^{121}$ In some way, the U.S. officers were correct in their predictions. In spite of the murder of Father Henrique and the escalation of the military repression, the Assembly did not end with a basic statement about Church-state relations. The Church, if anything, maintained what seemed the moderate position of February, an outcome that, in the opinion of the U.S., must have seemed disappointing for the progressives. ${ }^{122}$

\section{Collaboration for Social Change}

The interest of the U.S. in the Catholic Church made a significant leap in the year of 1969. Of the total of 167 documents and 552 pages for the 1964-1972 period, 61 documents and 249 pages are from 1969. As a consequence of the issuance of the AI5, that was a very intense year, full of skirmishes and confrontations. Moreover, 1969 started a very slow process of change in the American interest in the Church; a process that continued at least until 1972, the limit of this study.

The cautious position of the hierarchy after the AI5 contributed to the shift in the American view of the Church. Not a little contributed to the shift in the American view of the Church the moderate position of the hierarchy after the AI5. The spirit of that posture

\footnotetext{
${ }^{120}$ Telegram, Rio de Janeiro, July 15, 1969, State Department Cables, U.S. Embassy, Brasilia, National Archives, box 33.

${ }^{121}$ Report of conversation, July 10, 1969, State Department Cables, U.S. Embassy, Brasilia, National Archives, box 33.

${ }^{122}$ Report of conversation, Recife, August 12, 1969, State Department Cables, U.S. Embassy, Brasilia, National Archives, box 33.
} 
was deeply expressed in the conciliatory statement of February and the lack of any statement regarding Church-state relations in the General Assembly of July. Taking into account the previous American preoccupation with the disruption that the Church-state conflict brought to the regime, that new attitude (easily comprehensible on the other hand, bearing in mind the few options of the Catholic hierarchy) meant good news for the United States.

A conversation between Cardinal Dom Agnelo Rossi and officers of the Consulate in São Paulo following the CNBB meeting of February helps to understand some elements of the shift in the American view by 1969. In the conversation, the Cardinal expressed his preference for a "middle-of-the-road position" of the Church in regards to the regime. He criticized Dom Hélder for "provoking" the government and for his inappropriate criticisms of capitalism and U.S. policy. At the same time, the prelate expressed disagreement with the conservatives in the Church who favored the hardline military "one-hundred-percent.",123

Rossi said that he had opposed those who, in the meeting of February, wanted a stronger position of the Church regarding the AI5. In his opinion, that attitude would exacerbate the situation and the Church would lose capacity of influence over the regime. More interestingly, Rossi "appeared confident that the U.S. Government authorities would also find the message an excellent one with which we could agree." The attitude of Rossi, though conciliatory and moderate, was also characterized by a strong spirit de

\footnotetext{
123 Report of conversation, São Paulo, February 28, 1969, State Department Cables, U.S. Embassy, Brasilia, National Archives, box 33.
} 
corps. He had refused the National Order of Merit Medal the generals had awarded him with in order to "preserve his independence of [sic] the government."

The primary element of the emerging American rapprochement to the Church was a systematic effort to know it more deeply. During 1969 the Church, not only in Brazil but in Latin America in general, was the object of close observation as indicates a cable from the State Department on April of that year that deals with a systematic "intelligence estimate" on the Church. The cable asked the U.S. missions in Latin American countries for contributions to the study:

In particular, our interest is so far focused upon 1 the internal structure of the Church, [underlined in the original] its various factions and leaders as they relate to the problems of social, economic, and political development; 2 the social doctrines of the Church as they are interpreted by the Latin clergy, and particularly as they relate to reform, the development process, and violence as a means to achieve change; and 3 the alliances and relations with other groups, such as political parties, labor organizations, youth groups, and the military. We hope to reach some conclusions on the political and social significance of the Church in Latin America and the ways in which it is a force for and against various kinds of development there. ${ }^{125}$

This cable can be taken as a point of convergence of different American views of the Church. On one hand, the logics of the National Security Doctrine are still present, particularly in the second point that suggests likely inclinations of the churchmen to the use of violence. But the Church is also seen here as an agent of development and consequently a likely ally of the United States. That view of the Church would be

\footnotetext{
${ }^{124}$ Ibid.

125 Airgram, Washington, April 30, 1969, State Department Cables, U.S. Embassy, Brasilia, National Archives, box 33. All underlining in the original.
} 
recurrent in the next months and years and gradually diminished the vehemence of the National Security ideology in the cables.

Beyond any ideological position of the State Department, what is clear is that there was a deep interest in the Catholic Church, regarded as an actor of major relevance and influence in Latin American politics. This perception was the consequence of the intense political participation of the Church in 1968 and 1969. All four major reports (the most complete, deeply thought and best structured type of cable) for the whole 19641972 period were issued in mid-1969. ${ }^{126}$ Two of them dealt exclusively with the Church in the Northeast. It should be clear by now the reasons for the American special interest in the Church of that region.

A first report, 11 page long and entitled "Consulate General Seeks Broadened Dialogue with Northeast Churchmen," was issued in Recife on July 30 of $1969 .{ }^{127}$ The general framework of the cable was the need of the U.S. to seek dialogue with sectors disposed to and capable of social change in the Northeast. The military and the economic elites were major forces but the cable judged them unlikely to be inclined to social change. Since the issuance of the AI5 the political class of the region had been affected by cassation and cast out from the exercise of power, the students had been hit by punitive actions, organized labor was weak and divided, and the communications media had been censored.

\footnotetext{
${ }^{126}$ See the classification of the cables in the second chapter.

${ }^{127}$ Report, Recife, July 30, 1969, State Department Cables, U.S. Embassy, Brasilia, National Archives, box
} 33. 
Thus, the Church emerged as the most important actor for social change in the Northeast "simply by the process of elimination." The report advocated for "priority attention" to the Northeastern Church "both as a potential important political force affecting Brazil's future and as a potential agent for significant social change." But the cable also considered positively other elements (elements that had been judged unfavorably in the previous years) for the need of an intense U.S.-Church collaboration.

The cable dealt with the involvement of the Church in social change, the general criticisms among the churchmen of the U.S. policies and the situation of American clergymen in Brazil. In a pragmatic way, the cable asserts: "Despite outward appearances, we have found many churchmen willing and even eager to engage in meaningful dialogue, and some to be susceptible to influence. [...] The extensive links of churchmen through the region, within Brazil, and abroad, not only give our efforts here a potentially large multiplier effect, but it may also open alternative avenues of approach to this group." The State Department wanted to use the strengths of the Church to penetrate Brazilian society.

The report explained some approaches to Catholic and Protestant leaders in the Northeast, pointing out the reservations of the progressives but also their willingness to collaborate with the U.S. Out of the meetings with the religious leaders of the Northeast, which included the conspicuous Hélder Câmara and several American priests and missionaries, emerged the "subject of the preparation and training of churchmen and women," a subject that would grow in importance during the next weeks. 
A 17 page long cable was issued on August 22 also from Recife. It was the first part of a twofold report that, as a whole, dealt with the religious actors of the Northeast. The first was devoted to the Catholic Church and the second to other religious actors. This cable follows closely the guidelines of the cable from Washington of April (see note 115) and described the relevance of the Church in the Northeast, its conflicts with the military, its inner debates, its finances, the functioning of the institutional structure and the relation with other sectors. The cable still shows the sort of concern characteristic of the National Security Doctrine:

Radicals and some progressives, among the Northeast clergy are not completely intimidated, moreover, by the Church's theoretical rejection of violence. Rather, they tend to give some degree of acceptance to the counter-argument that institutionalized violence already exists, and that by taking arms the people would be really acting only in self-defense. Dom Fragoso, Archbishop José Maria Pires of João Pessoa, and even Dom Hélder himself, have indicated varying degrees of sympathy with this line of argument. ${ }^{128}$

Nonetheless, this cable, as the previous major report, also depicted the Church in the Northeast mainly as an "institutionalized force for modernization of the economic and social structure which is essential to development in the Northeast." A most important element of this report is the focus on all the aspects related to priesthood. It delved into the "crisis in the recruitment of priests," the consequent relevance of the foreign clergy, and even the political postures of the priests according to their nationalities.

\footnotetext{
${ }^{128}$ Report, Recife, August 22, 1969, State Department Cables, U.S. Embassy, Brasilia, National Archives, box 33 .
} 
For obvious reasons, the interest augmented when it came to American clergy. The cable concluded that the American priests were neither as traditionalist as Italians, Portuguese and Brazilians nor as radical and compromised as the Dutch and Germans. American clergy would follow a rather Protestant-like line that encouraged participation of laity and "get close to the people at the lowest economic and social levels." American officers seemed interested in reaching those levels of Brazilian society.

A third major report came in September but this one broadened the perspective from the Northeast to the whole country. The cable of 27 pages was signed by Ambassador Charles Elbrick who had replaced John W. Tuthill in March of $1969 .{ }^{129}$ The report went along the same lines of the previous two, focusing on institutional information such as "the native and foreign priesthood, recruitment of priests, Church attendance, the role of the laity, current church educational and labor policies, the ecumenical movement and its radical tendency." ${ }^{\prime 130}$

Moreover, this cable stressed some elements that had been emerging in the previous reports, namely the crisis of vocations to the priesthood, the situation of foreign priests and the diverse elements of clergy recruitment. The U.S. had noted that by the end of the 1960s, one of the biggest problems of the Brazilian Church was the massive abandonment of priesthood, particularly by young and progressive priests, who were feeling frustrated by the difficulties in implementing the reforms of the Council.

\footnotetext{
${ }^{129}$ Green, We Cannot Remain Silent, 102.

${ }^{130}$ Report, Rio de Janeiro, September 5, 1969, State Department Cables, U.S. Embassy, Brasilia, National Archives, box 33 .
} 
On the other hand, during 1969, after the scandal around Father Comblin's study, and particularly after the expulsion of the Oblates, foreign priests, particularly the Americans, demanded the attention of the U.S. ${ }^{131}$ In several cables, the Foreign Service provided quantitative and qualitative information as queried by Washington. ${ }^{132}$ A cable of June, for instance, as a response to the instructions of the CIA, provided detailed information about the ideological postures of foreign clergymen who would be "pushing too hard for social and economic reforms." The cable also dealt with the attitudes of the Brazilian priests towards their fellow American churchmen. In their answer, the American diplomats drew the panorama of the different political postures and approaches to social reality in accordance to the nationality of the priests. Yet, at the same time, the cable showed sincere concerns about the security of the American priests in Brazil. ${ }^{133}$

A fourth major report, issued in Recife on October, should help to understand how the American interests in the crisis of priesthood, the situation of the foreign priests and the diverse elements of clergy recruitment are connected. On the basis of the perception of the Church's "significant potential as an agent of development and social change," and taking into account "the many setbacks and frustrations which individual

\footnotetext{
131 Report of conversation, Recife, June 9, 1969, State Department Cables, U.S. Embassy, Brasilia, National Archives, box 33.

132 Telegram, Rio de Janeiro, May 15, 1969, State Department Cables, U.S. Embassy, Brasilia, National Archives, box 33 .

133 Report, Rio de Janeiro, June 27, 1969, State Department Cables, U.S. Embassy, Brasilia, National Archives, box 33 .
} 
clergymen endure in their difficult and frequently misunderstood social-action oriented pastoral activities," the cable outlined a likely U.S.-Church cooperation. ${ }^{134}$

The cooperation would consist of American assistance in the training of priests, foreign or Brazilians, in order to strengthen "the ability of the Catholic and other Churches in Brazil to contribute to development." The report proposes a few likely programs and explores the ways to make them possible. Not only the U.S. and the Brazilian Catholic Church would participate in the programs but also the American Catholic Church, universities and institutions such as the Center for Inter-Cultural Formation (Centro de Formação Intercultural, CENFI) in which foreign churchmen, diplomats and lay people were oriented when arriving to Brazil. According to the cable, American officers had been consulting with the religious leaders of the Northeast for the formulation of these plans.

In perspective, the proposal was the outcome of that systematic effort at gathering information about the Church in 1969. Clearly, the increasing interest of the State Department and other agencies in the situation of the foreign clergy and the priesthood crisis was pragmatic. The crisis of the Church meant an opportunity for the U.S. that saw the American religious missions in Brazil as an opportunity to penetrate and influence the Church.

Gradually, after 1969 the suspicion towards the Church that was so evident in the cables of the first five years of dictatorship became less vehement. The Church was

\footnotetext{
${ }^{134}$ Report, Recife, October 1, 1969, State Department Cables, U.S. Embassy, Brasilia, National Archives, box 33 .
} 
increasingly seen as an agent with an enormous capacity for social change and less as a threat to the stability of the regime. The language of National Security was giving room to a spirit of collaboration for social change and modernization.

In all these major cables of 1969 , the American officers constantly mentioned the criticisms of the progressive Northeastern churchmen of the U.S. Even though the hierarchy had some hopes in a likely alignment of the American government with human rights issues, the churchmen openly reproached the U.S. through the diplomatic officers. This would also stimulate the desire to influence the Church in order to change the negative image it had of the U.S.

In this regard, it is noteworthy that the new "collaboration for social change" approach was focused on the Northeast, where the Church was more progressive and likely to criticize the U.S. It could easily be interpreted that the American agencies were trying to encourage their own view of social change in the Northeast in order to counteract the relevance of the most progressive views;

The collaborationist view of the Church emerged in the aftermath of the AI5 and the international concern for the human rights situation in Brazil. The aforementioned subtle shift in the U.S. view of the regime had as a consequence an American rapprochement to the democratic sectors of Brazil. ${ }^{135}$ Sooner or later, probably as a consequence of international pressure, the military would go back to the barracks and those sectors would take back the reins of the Brazilian state. Nevertheless, most of the democratic opposition had gotten smashed by the repression. Unlike parties and

${ }^{135}$ Green, We Cannot Remain Silent, 95. 
collegiate bodies that depended on the state, the Church was not only independent but rivaled it in political importance and social scope.

Therefore, although the lay organizations of the base and the Catholic press were dismantled or silenced, the CNBB not only remained standing but was even gaining in cohesion and international support. The deepening of the repression during 1968, the threats against foreign priests and the issuance of the AI5 were awakening an international consciousness. Furthermore, the Brazilian Church was getting the attention

of the Vatican and building fruitful relations with the American Catholic Church, brazilianist scholars, the protestant churches and emergent organizations for the defense of human rights. At least in the case of the Oblates, the U.S. could feel sympathy for the persecuted and repressed of Brazil.

\section{The Transformation of the Church}

Still, during the second half of 1969 the U.S. officers kept reporting on situations that affected Church-state relations. The most relevant of these events was the arrest and torture of members of the Dominican order who were linked to leftist groups in arms. Faithful to the posture adopted after the issuance of the AI5, the bishops refrained from public and open confrontation with the military. Thus, these situations did not ignite the public confrontation of other times. Although some U.S. officers understood the "prudence" of the Church as a blow to the progressives, the Church was plainly not accepting of the behavior of the military. A strong institutional discourse and praxis of protection of human rights was emerging. Around human rights, the Brazilian Church would reach its moment of greatest union and became the main opponent to the regime. 
The moderate attitude of the Church was tied to the growing leadership of Dom Eugênio de Araújo Sales. ${ }^{136}$ Repression in Salvador had been fruitful in breaking the student and lay movement that had maintained the Northeast as a fortress of the liberationists. The appointment of Dom Eugênio as archbishop of Salvador in October of 1968 was seen by the U.S. as a blow to the progressivism in the Northeast and particularly to that of the Benedictines of the São Bento Monastery. ${ }^{137}$ The U.S. officers judged that with him in Salvador, Dom Timóteo Amoroso Anastácio and Dom Jerônimo de Sá, largely regarded as controversial, would lose ground. However, by 1970 they were still in the sights of the U.S. officers. ${ }^{138}$

Yet, the figure of Dom Eugênio was too complicated to fit into the conservative/progressive scheme. As a matter of fact, the American cables of the time contradicted each other by regarding him at times as conservative and at times as progressive. ${ }^{139}$ What is clear is that Dom Eugênio was stamping a cautious attitude in the Church in which there were strong criticisms against the government for human rights violations though through institutional ways. "He [Eugênio] seemed especially interested in trying to portray the Church and himself as vigorously involved in the struggle against

\footnotetext{
${ }^{136}$ Report of conversation, Salvador, May 2, 1969, State Department Cables, U.S. Embassy, Brasilia, National Archives, box 33 .

${ }^{137}$ Report of conversation, Salvador, April 10, 1970, State Department Cables, U.S. Embassy, Brasilia, National Archives, box 39.

${ }^{138}$ Report of conversation, Salvador, April 2, 1970, State Department Cables, U.S. Embassy, Brasilia, National Archives, box 39.

${ }^{139}$ Kenneth Serbin does a contemporary insightful interpretation of Dom Eugênio in Secret Dialogues, 66.
} 
torture, murder and other violations of personal liberties committed by police and other security officials." ${ }^{, 140}$

Broadly, that was the policy followed by the Central Commission of the CNBB in the meeting of February of 1970 . Then, the Church officially adopted the posture of low key dialogue that had been striving to reach during one year. During 1970 the Church was still the object of intense observation by the U.S. diplomatic corps. Although the flux of cables lowered considerably in comparison to the previous year, 1970 was the second most important year of the U.S. interest in the Brazilian Church for the 1964-1972 period, with 42 documents and 110 pages.

For those who interpreted the new position of the Church as harmless to the state, the annual Assembly of bishops on May of 1970 would prove them wrong. In that meeting, the bishops continued to follow the policy of avoiding open confrontation but at the same time they strongly repudiated the use of torture. ${ }^{141}$ The fact that the resulting pastoral letter of the meeting, issued on May 27, included a statement that totally condemned the human rights violations was an achievement in comparison to the lack of agreement of the previous year. ${ }^{142}$

The outcome of the Assembly of May was a direct consequence of the systematic persecution the Church had suffered since 1968 and the deepening of the repression after

\footnotetext{
${ }^{140}$ Report of conversation, Salvador, April 12, 1970, State Department Cables, U.S. Embassy, Brasilia, National Archives, box 39.

${ }^{141}$ Telegram, Rio de Janeiro, May 30, 1970, State Department Cables, U.S. Embassy, Brasilia, National Archives, box 39 .

${ }^{142}$ Telegram, Brasilia, May 26, 1970, State Department Cables, U.S. Embassy, Brasilia, National Archives, box 39 .
} 
the AI5. On one hand, the repression was successfully undermining the grassroots that constituted the support of the progressive bishops; in consequence, the conservatives were having more room for manoeuver and were exerting considerable pressure on the most outspoken progressives to stop their denunciations of the social calamities.

However, at the same time, most churchmen discerned that the persecution was not limited to the progressive sector but it was directed to the Church as a whole. The murder of father Henrique, but also the successful Assembly of CELAM awakened the esprit de corps of the majority of the bishops, regardless of their political posture. Since 1969, those bishops commonly held as conservatives had been giving signals of disappointment with the regime and the southern churchmen started supporting more decisively the northeastern ones.

In January of 1969, for instance, the Foreign Service had noticed that Dom José Lafaiette, auxiliary bishop of São Paulo, who was usually portrayed as conservative, was "outraged" by the regime. Feeling that his Church was being seriously challenged, he would "react vigorously." The American officers noted that in this regard, his position "appeared to differ very little from that of the progressive Dominicans.",143

Another cable, of February of 1970, described a very similar situation for archbishop of Goiana, Dom Fernando Gomes dos Santos: "Having been the target of criticism from the left wing prior to the revolution of 1964 he now finds himself equally

\footnotetext{
${ }^{143}$ Report of conversation, São Paulo, January 8, 1969, State Department Cables, U.S. Embassy, Brasilia, National Archives, box 33.
} 
critized [sic] by the group in power in 1970." ${ }^{144}$ I have also mentioned how Dom Jaime de Barros Câmara had resented the expulsion of the Assumptionists. Since 1969 he and Dom Eugênio had become vocal in the defense of human rights.

The signs of discomfort from conservative and moderate bishops continued at least until the end of the period that this study covers. In September of 1971, Dom Avelar Brandão Vilela, one of the most prominent moderates, with close ties to the military and also the president of the Latin American Episcopal Conference since 1968, gave a speech at the Superior War College. On that occasion, the bishop not only criticized openly the National Security Doctrine and the repression of youth and dissidents but went as far as taking to task the regime "for not improving the distribution of wealth, observing that in Brazil rich becoming richer and poor poorer." ${ }^{" 145}$ The disappointment was massive.

The defense of human rights and the denunciation of torture were cohesive factors for the episcopate that adopted a determined and institutional position in the defense of its militants, churchmen and anybody affected by the repression. The commitment of the Church to human rights was an international issue per se. Facing the strict limitations in Brazil, the Church, the exiles and the defenders of human rights resorted to the international community, and to the Vatican in particular, which fully supported the Brazilian Church.

\footnotetext{
${ }^{144}$ Report of conversation, Brasilia, February 6, 1970, State Department Cables, U.S. Embassy, Brasilia, National Archives, box 39.

145 Telegram, Rio de Janeiro, September 27, 1971, State Department Cables, U.S. Embassy, Brasilia, National Archives, box 57.
} 
A central pillar of the Church's praxis in the defense of human rights was the Brazilian Commission for Justice and Peace. The Commission had been in gestation since the meeting of CELAM in Medellin and was officially created on October of 1969. ${ }^{146}$ This transnational enterprise helped to transform the perception of the Brazilian Church from an institution that inappropriately got involved in politics, into a champion of human rights and a legitimate institutional dissident. Gradually, the Church was becoming the most critical antagonist of the regime. Ironically, in doing so, the Church had silenced the most progressive of its individual voices.

In the following weeks after the assembly of the CNBB of May, bishops and generals, both trying to hide their internal fissures, were trying to get to agreement. A partial result would be achieved by July: "source stated that GOB, increasingly sensitive to damage international image and prestige, proposed quid pro quo in which $\mathrm{CNBB}$ would refrain from all activities to propagate stories violence abroad and GOB would take reciprocal steps to reduce chances mistreatment prisoners." ${ }^{\text {"47 }}$ This indicates that the human rights campaign was having success.

Precisely, that success of the international campaign for human rights enraged the military, who intensified the persecution of Catholic organizations such as the Catholic Youth Workers and the ACO in the second half of $1970 .{ }^{148}$ At the height of the

\footnotetext{
${ }^{146}$ Cândido Mendes and Marina Bandeira, Comissão Brasileira Justiça e Paz (1969-1995): Empenho e memória (Rio de Janeiro: Educam, 1996), 61.

${ }^{147}$ Telegram, Rio de Janeiro, July 25, 1970, State Department Cables, U.S. Embassy, Brasilia, National Archives, box 39 .

${ }^{148}$ Report, Rio de Janeiro, October 9, 1970, State Department Cables, U.S. Embassy, Brasilia, National Archives, box 42.
} 
persecution in October, the police broke into the offices of the Jesuit Brazilian Development Institute (Instituto Brasileiro de Desenvolvimento, IBRADES) in Rio de Janeiro and detained the occupants, including bishop Dom Aloísio Lorscheider. ${ }^{149}$

If that was not enough, the use of torture was becoming massive. In a cable from the northern city of Belem of September 14, an American priest gave details of the torture of father José Antonio Monteiro Magalhães, who had been arrested with the French priest Xavier de Maupeon in August in the city of São Luis. ${ }^{150}$ This sort of actions, which were internationally denounced by the Church with the support of the Vatican, undermined the image of the Brazilian regime overseas. ${ }^{151}$

Meanwhile, some bureaucratic changes were taking place within the Church. In October 23 of 1970, Cardinal Agnelo Rossi was appointed director of the Sacred Congregation for the Propagation of the Faith (also known as Congregation for Evangelization of Peoples) and was replaced in the archdiocese of São Paulo by bishop Dom Evaristo Arns. This was an important moment for the commitment of the Church to human rights. From São Paulo's archbishopric palace, Dom Evaristo would lead the Church's mission in protection of human rights. ${ }^{152}$

\footnotetext{
${ }^{149}$ Telegram, Rio de Janeiro, October 21, 1970, State Department Cables, U.S. Embassy, Brasilia, National Archives, box 39 .

${ }^{150}$ Report of conversation, Belem, September 14, 1970, State Department Cables, U.S. Embassy, Brasilia, National Archives, box 39.

151 Telegram, Brussels (Belgium), October 21, 1970, State Department Cables, U.S. Embassy, Brasilia, National Archives, box 39.

${ }^{152}$ Telegram, São Paulo, October 23, 1970, State Department Cables, U.S. Embassy, Brasilia, National Archives, box 39 .
} 
A first round between Dom Evaristo and the regime was the trial, during February and March of 1971, of the Italian priest Giulio Vicini and the social worker Yara Spadini, who had been arrested and accused of subversion and militancy in the AP. ${ }^{153}$ American cables followed the details of the trial, constantly assessing the state of the political confrontation between the bishop and the military. ${ }^{154}$ In a report of September 9 that deals entirely with the situation of the Church during the first months of the year, the bishop's defense of the two indicted was described as a "position that invited confrontation," whose objective was to assure for Arns a prominent role in the CNBB conference that took place in February of $1971 .^{155}$

\section{The Church and Human Rights}

The nine day meeting of the episcopate in February of 1971 in Belo Horizonte was a milestone for the Brazilian Catholic Church, implying a change of cycle. The CNBB had been marked by deep divisions and multiple agendas but in the two previous years had been trying to reach a minimal consensus to make the Church act as a united institution. The meeting of February of 1971 was the culmination of those efforts.

The central point of the meeting was the election of new officers for the conference. With the departure of Cardinal Rossi to the Vatican some months ago, the

\footnotetext{
${ }^{153}$ Telegram, São Paulo, February 12, 1971, State Department Cables, U.S. Embassy, Brasilia, National Archives, box 51.

154 Telegram, São Paulo, March 4, 1971, State Department Cables, U.S. Embassy, Brasilia, National Archives, box 51.

${ }^{155}$ Report, Rio de Janeiro, September 9, 1971, State Department Cables, U.S. Embassy, Brasilia, National Archives, box 51. The trial ended on March 31 when Spadini was absolved and Vicini was found guilty and condemned to 6 months in prison that were later reduced to 4. In August the Supreme Military Tribunal reversed the decision and absolved Vicini of the charges.
} 
Church was in the need for a new reorganization in the structure of the Conference. Dom Aloísio Lorscheider, bishop of Santo Angelo, succeeded Rossi in the presidency. His cousin Dom Ivo, auxiliary of Porto Alegre, succeeded Dom Aloísio as General Secretary. Dom Avelar Brandão Vilela, bishop of Teresina and president of the CELAM, was elected vice president to replace of Dom Alfredo Vicente Scherer. Other important posts were also submitted to election, including the regional representatives to the Conference. ${ }^{156}$

A 22 page long report issued on September by Ambassador William Rountree, who had replaced Charles Elbrick at the end of 1970, went into the details of the meeting. For the U.S., it was symbolically powerful that the bishops elected Dom Aloísio, who had been detained by the military, though only for a few hours, in October of 1970 , as president of the Conference. Moreover, Dom Ivo, the new secretary, was actually held as a progressive.

The ambassador remarked on the issuance of several documents at the end of the meeting that included a "proclamation presenting the basic orientation of the Church in today's Brazil," a total political success since it expressed consensus and set guidelines for the role of the Church in the medium-term. Furthermore, the CNBB issued open letters of support to Dom Evaristo Arns, Dom Waldyr Calheiros and the Dominican Order of São Paulo. The first was by then involved directly in the trial against the aforementioned Italian priest and the second was one of the top leaders of the progressive

\footnotetext{
${ }^{156}$ Ibid. The death of Cardinal Dom Jaime in February 18 caused a restructuration in the dioceses as well. Dom Eugênio replaced him as archbishop of Rio de Janeiro and was in turn replaced by Dom Brandão in Salvador.
} 
sector and was leading a campaign for the defense of human rights in his diocese of Volta Redonda. Finally, the Dominicans of São Paulo were a common target of the regime that accused them of terrorism and subversion. A final aspect of the meeting, of deep symbolic connotation, was picked up by the ambassador:

This support of three churchmen, who in the public mind at least were thought to represent active opposition to and confrontation with the State, was interpreted by many observers at the time as a signal that the CNBB was ready to move into an open position of greater opposition to the Government. The elections of more liberal CNBB officers seemed to confirm this hypothesis. So did the convention's selection of a representative to give the closing statement to the assembled press corps. In a blunt challenge to the GOB, Dom Helder [sic] CAMARA, Archbishop of Olinda and Recife and outspoken leader of the progressive wing of the hierarchy (whose very name is anathema to the GOB), broke three years of silence vis-à-vis the Brazilian press. He did so dramatically by presenting a summary of the meeting and the various manifestos. ${ }^{157}$

Something that does not appear in the cables which is vital to understand this important shift in the Church is the nature of the repression during the second half of 1970. In previous years the bishops had been at least partially successful in negotiating and interceding for the victims of the repression by direct communication with the highest circles of the military establishment. In the last months, however, the military had been deliberately reluctant to accede to the petitions of the episcopate. Kenneth Serbin notes:

Fearful of being associated with the revolutionaries, naively confident of the religious sentiment of the generals, and accustomed to social privilege, the bishops had taken years to understand the violent nature of the regime, which the Jocistas [Catholic Youth Workers] and other grassroots

${ }^{157}$ Ibid. 
militants had known all too well from the horrors of the jails. The bishops came to this realization only after the detention of Dom Aloísio "directly wounded" the bishops, forcing them "to take up a position of defense." 158

The bishops negated that the Church was moving towards open conflict with the regime, something that, on the other hand, was never anything other than a press construction. Even in the moments of most dangerous tension, the episcopate, including most of the progressives, showed openness to dialogue with the military. ${ }^{159}$ At least according to the cables of the Foreign Service, the U.S. was not too aware of the Bipartite Commission, the space for high level dialogue between Church and government that started meeting since November of 1970 and that is described in detail by Kenneth Serbin. $^{160}$

For the remainder of 1971 and during 1972, the U.S. diplomats kept reporting on the Church, focusing again on its relations with the military. Confrontations took place as in the previous years with peaks and valleys determined by the legal or illegal actions against members of the Church and increasingly by facts of torture and violations of human rights. In June of 1972, for instance, thirty-six political prisoners, including three Dominican churchmen, started a hunger strike in protest against inhuman conditions that lasted more than one month and ended with the mediation of bishop Dom Evaristo Arns. A telegram of those days read: "Archbishop Arns left Sao Paulo [sic] for visit to Europe

\footnotetext{
${ }^{158}$ Serbin, Secret Dialogues, 87-88.

${ }^{159}$ Report, Rio de Janeiro, September 9, 1971, State Department Cables, U.S. Embassy, Brasilia, National Archives, box 51.

${ }^{160}$ Serbin, Secret Dialogues, 92.
} 
and U.S. and in departure statement to press raised hunger strike. He said that again he had been denied access to prisoners. $" 161$

The transnational power of the Church had become the main problem of the military. By 1972, as a consequence of the continuous denunciation of torture, the image of the regime in European and American public opinion was irreparable. ${ }^{162}$ The case of the priest, Gerson da Conceição de Almeida, is very indicative in this regard. In a cable from Washington on July of 1972, there appears a sympathetic concern for the fate of the persecuted: "Senator Harris requests information on charges against Gerson da Conceicao [sic], the state of his health, the address and names of his family, and if he can be contacted by mail through the proper authorities."

Father Gerson had been arrested with four lay people on October of 1971 in the southeastern estate of Espírito Santo. All of them belonged to a Catholic organization of social and educational assistance that had been founded by the American priest Edmund Nelson Leising. Father Gerson was imprisoned in Vila Militar in Rio de Janeiro without being formally charged of any crime. Gerson and his friends had been submitted to torture and one of them, Lucio de Brito Castelo Branco, had been placed on provisional liberty as he "needed special medical attention as a result alleged mistreatment." 164 All of

\footnotetext{
161 Telegram, São Paulo, June 23, 1972, State Department Cables, U.S. Embassy, Brasilia, National Archives, box 57.

162 Telegram, São Paulo, July 28, 1972, State Department Cables, U.S. Embassy, Brasilia, National Archives, box 68 .

163 Telegram, Washington, July 26, 1972, State Department Cables, U.S. Embassy, Brasilia, National Archives, box 68 .

${ }^{164}$ Telegram, Rio de Janeiro, July 31, 1972, State Department Cables, U.S. Embassy, Brasilia, National Archives, box 68 .
} 
this information was provided by Leising himself to American officers in Rio de Janeiro who added:

Embassy feels that extreme GOB sensitivity to what it would view as unwarranted interference in its internal affairs by USG precludes providing all of above unconfirmed information to Senator Harris, particularly if he intends to release and attribute it to either department and/or US embassy Brazil. Would therefore suggest following draft language possible reply for department's consideration. ${ }^{165}$

This cable shows the general sentiment of the military regime that was increasingly feeling isolated and overwhelmed by criticisms from abroad. It is very revealing that the military authorities would regard the American diplomatic corps in Brazil as a threat. Any network and institution with international scope, such as the academic community or the Church, represented a threat to the government. The main concern of the military was to conceal from the world their reiterated violations of human rights. Evidently, both the power relations among the Brazilian institutions and the American view of the country had undergone important changes in eight years.

${ }^{165}$ Ibid. 


\section{CHAPTER 5}

\section{Who is Observed?}

The intense observation of the progressive members and sectors of the Catholic Church by the U.S. was primarily related to the American view of those historical actors as dangerous and threatening. That view was determined by the progressives' opposition to the dictatorship as well as by their eventual relation with ideologies held as revolutionary. Other important actors within the Church who did not represent a threat to the military regime garnered scarce attention.

Tradição, Família e Propriedade (TFP) was recognized as an "ultra-rightwing" and "archconservative" Catholic movement that counted on the support of the regime in its confrontation with the progressive Catholics. ${ }^{166}$ Inspired by the corporativist and fascist regimes in Spain under Francisco Franco and Portugal under António de Oliveira Salazar, this group propagated corporatist and authoritarian ideas and was disdainfully regarded by the U.S. Although it did represent a threat to democracy, TFP appeared in only a handful of cables. In the same way, right wing bishops like Dom Sigaud and Dom Castro Mayer were not on the radar of the officers as were the progressives.

\footnotetext{
166 Telegram, Rio de Janeiro, June 26, 1969, State Department Cables, U.S. Embassy, Brasilia, National Archives, box 33 .
} 


\section{Students}

Organizations like the Movement for Basic Education, Catholic Youth Workers and Catholic University Youth, among others, were the subject of intense observation and concern. Those organizations were immense lay structures in which the so-called communist infiltration took place. However, as the repression deepened after the AI5, those weakened organizations gradually disappeared from the cables. Of particular concern for the U.S. was the relation between the Church and the students.

The students and youth in general were the main objective of the state repression during the National Security dictatorships of the Southern Cone. Although in the first years of the Brazilian regime there was an evident split between the majority of the episcopate hierarchy and the students, there remained a strong relation between some bishops, priests, lay activists and the student organizations.

Church-student relations involved two main problematic issues from the perspective of the U.S. officers. On one hand, the students, regarded as the breeding ground for terrorism and subversive movements, would influence negatively the churchmen and carry out the worrisome communist infiltration in the Church. On the other hand, since the very beginning of the dictatorship, the U.S. showed concern about the protection that the Church, particularly the orders and the progressive bishops, afforded to the students.

That was one of the causes of the Church-state conflict that worsened in 1968 when the majority of the churchmen seemed decided to protect the students from state 
repression. In the aftermath of the AI5, the students were no longer a worry. Not only had the repression undermined the movement's capacity of mobilization but there was a rupture with the Church. The moderate institutional approach of the Church and the consequent appeasement of the socioeconomic criticisms, particularly since 1969, made the youth feel abandoned by the hierarchy.

\section{Bishops}

Unlike the grassroots, which gradually lost relevance in the American cables after the deepening of the repression, the bishops were the most conspicuous sector from beginning to end. The conversations of American ambassadors, consuls and officers with bishops reveal a growing effort by the U.S. to establish good and collaborative relations with them. The bishops, on the other hand, always showed themselves receptive and open to dialogue with the American Foreign Service. A sign of this is the high quantity of conversations between churchmen and the U.S. officers.

The main referent for the U.S. in regards to the Brazilian Catholic Church was the CNBB. The Conference of Brazilian Bishops was certainly the head of the national Church and the space that gathered most of its leadership. Changes in the balance of forces within the CNBB always affected enormously the rest of the Church; its annual meetings, general conferences and declarations were taken as navigational charts. Finally, readjustments in the top posts of the $\mathrm{CNBB}$ had enormous consequences for the direction the Church would take on very important issues. 
Thus, the U.S. followed closely the meetings of the CNBB and the variations in the balance of power between progressives and conservatives. The public declarations that most of the time followed the meetings of the CNBB were always monitored and the quantity of cables dealing with the Church invariably increased as the meetings approached. Clearly, the American diplomats were interested in the reactions and institutional postures of the CNBB in regards to the regime.

Naturally, the U.S. sought to create close ties with the main leaders of the Church: the archbishops of Rio de Janeiro, São Paulo and Salvador, presidents and secretaries of the CNBB and the Apostolic Nuncio. Two of the most usual interlocutors of the Foreign Service were Dom Agnelo Rossi and Dom Eugênio de Araújo Sales. The American officers were always eager to know the postures of these bishops and held in high esteem their opinions.

Dom Eugênio was particularly regarded as a top and ascending leader, an opinion that seemed to be shared by other personalities outside the Church. ${ }^{167}$ Dom Eugênio was bishop in Salvador da Bahia, first as administrator since 1964 and as Archbishop after 1968. In April of 1969, he was elevated to Cardinal and in March of 1971, became Archbishop of Rio de Janeiro, quite a stunning career that seemed to accord with the capacities of the bishop.

I have pointed out some contradictions in the U.S. interpretation of Dom Eugênio. In a cable of May of 1965, he is held, together with Dom Hélder and Dom Jerônimo, as a

\footnotetext{
${ }^{167}$ Report of conversation, Brasilia, March 8, 1968, State Department Cables, U.S. Embassy, Brasilia, National Archives, box 24.
} 
leader of the "social minded Catholic priests." 168 Several times, when asked about Dom Hélder, Dom Eugênio expressed sympathy and proximity to the thought of the bishop of Olinda and Recife. However, in a conversation with the Consul of Salvador, Harold M. Midkiff, also on May of 1965, Dom Eugênio mentioned "some mistakes" of Dom Jerônimo and referred to Popular Action as a "dangerous organization." 169

Later on, in April of 1969, a cable read: "The reporting officer detects a subtle change in Dom Eugênio's attitude vis a vis the Military Regime (towards greater tolerance) possibly because of his new status in the College of Cardinals, and perhaps as the result of policy emanating from the Vatican." ${ }^{, 170}$ Finally, for the Foreign Service, the appointment of Dom Eugênio as bishop of Rio de Janeiro was consequence of his good relations with the military. Dom Eugênio was the choice of the Vatican against the wishes of the local clergy who preferred the more progressive, Dom Aloísio. ${ }^{171}$ An accurate view would define Dom Eugênio as a very pragmatic figure who was highly interested in maintaining the public role of the Church through institutional means. ${ }^{172}$

Some bishops were subject to deep observation not for their relevance in the balance of power within the Church but for their links with grassroots and students, their

\footnotetext{
16812 Biographic data form, Rio de Janeiro, May 13, 1965, State Department Cables, U.S. Embassy, Brasilia, National Archives, box 5.

${ }^{169}$ Report of conversation, Salvador, May 21, 1965, State Department Cables, U.S. Embassy, Brasilia, National Archives, box 5.

${ }^{170}$ Report of conversation, Salvador, April 17, 1969, State Department Cables, U.S. Embassy, Brasilia, National Archives, box 33.

171 Telegram, Brasilia, March 31, 1971, State Department Cables, U.S. Embassy, Brasilia, National Archives, box 51.

${ }^{172}$ Report of conversation, Salvador, November 5, 1970, State Department Cables, U.S. Embassy, Brasilia, National Archives, box 39 .
} 
criticisms of the socioeconomic situation and their skirmishes with the regime. Some of the more interesting for the U.S. were Dom Serafim Fernandes de Araújo of Belo Horizonte, Dom José de Medeiros Delgado of Fortaleza and Dom Antônio Batista Fragoso of Crateús. All of them were usual suspects in the U.S. view. Dom Fragoso, for instance, was held as a highly controversial figure who had expressed sympathy for Cuba, a crime of lese-empire by the time. ${ }^{173}$

There was a particular interest in the São Bento Monastery of Salvador that was led by the Benedictines Dom Jerônimo de Sá Cavalcante and Dom Timóteo Amoroso Anastácio. They were seen as particularly suspicious for their progressive ideas and their commitments to the student movement. Other than Dom Serafim, all of these churchmen lived in the complicated Northeast. It is clear that the bishops from that region were regarded as particularly dangerous.

\section{Dom Hélder Câmara}

Dom Hélder Câmara stood out among the progressive bishops for his revolutionary thought and the national and international recognition that he had as a religious leader. For the Diplomatic Service there was no one more controversial, important or dangerous than he. Dom Hélder was the reference of the American officers for understanding the progressive wing of the Church; thus his name was present in most of the cables of the period and there was a consistent effort in gathering information about his public interventions, reactions, travels, contacts and other activities.

\footnotetext{
${ }^{173}$ Report of conversations, Brasilia, April 26, 1968, State Department Cables, U.S. Embassy, Brasilia, National Archives, box 24.
} 
In 1964, Dom Hélder was a rising international religious leader. In the next years he would be given honorary doctorates from Harvard, the Sorbonne and 30 other universities around the world. ${ }^{174} \mathrm{~A}$ master of public relations, until the dictatorship Hélder was always a friend or acquaintance of the presidents in turn. Other than the soccer player Pelé, Dom Hélder was probably the most famous person from Brazil in the 1960s and 1970s. Because of his international recognition, during the dictatorship he, besides the intellectual Alceu Amoroso Lima, was probably the only dissident with a free voice. $^{175}$

Hélder Câmara was born in Fortaleza in 1909 and was ordained a priest when he was 22 years old. Since his youth, Hélder became involved in programs of public education of the state of Ceará, at a time when it was very common for priests to occupy bureaucratic posts. Naturally inclined to politics, Hélder had been a member of the ultraright movement of integralismo. In 1936, Hélder moved to Rio de Janeiro where he abandoned integralismo and moved closer to progressive intellectuals, politicians and churchmen; some of them were living the ideological transformation from traditionalism into rather liberal postures that he was living.

In Rio, Hélder befriended the lawyer Sobral Pinto, the intellectual Alceu Amoroso Lima, the politician Santiago Dantas and the future bishop José Vicente Tavora; all of them were or would be key elements of the progressive circles of Brazil. In 1947, Hélder became vice-assessor general of the Catholic Action under the supervision of the

\footnotetext{
${ }^{174}$ Regan, Why are They Poor?, 43.

${ }^{175}$ Zildo Rocha, Hélder, o Dom: Uma vida que marcou os rumos da Igreja no Brasil (Petrópolis: Vozes, 1999), 62.
} 
Cardinal Câmara, just at the moment in which the movement was strengthening and completing its transformation in a specialized pastoral movement of the French variety. ${ }^{176}$

Hélder had always shown leadership skills and abilities in communication. He was central for the growth of the Catholic grassroots movement during the 1940s and 1950s. In Catholic Action, Hélder opened up his horizons and developed a broad view of his Church and his country. The national organization of Catholic Action inspired him to create the National Conference of Bishops of Brazil that came to life in 1952 as was already mentioned. ${ }^{177}$ That same year, Hélder was named Auxiliary Bishop of Rio de Janeiro and first General Secretary of the CNBB.

In 1955, during the International Eucharistic Congress of Rio de Janeiro, organized by him and his task team, Hélder, in association with Bishop Manuel Larrain of Chile, organized the first General Assembly of CELAM, the conference of Latin American bishops. Hélder had become a national celebrity and a promising leader of the Latin American Church. During the Vatican Council, Dom Hélder played an important role in strengthening the position of the progressive bishops and gained worldwide recognition as a dynamic leader.

Human dignity, social justice and peace were the backbone of Dom Hélder's thought; a global perspective that took into account the economic, political and spiritual dimensions of humanity. For him, the achievement of those mutually inclusive objectives was a revolutionary and necessary process. The centrality of non-violence in Dom

\footnotetext{
${ }^{176}$ Bidegain, La Organización de Movimientos, 128.

${ }^{177}$ Regan, Why are They Poor?, 48
} 
Hélder's thought made him close to figures like Martin Luther King, Mahatma Gandhi and Nelson Mandela, leaders with whom the bishop felt deeply identified. Like them and like the biblical prophets, Dom Hélder was a tireless critic of the status quo and like them he faced persecution. In his position regarding capitalism, Dom Hélder, who was always open to dialogue, built bridges with elements of Marxism. ${ }^{178}$ Nevertheless, this did not stop him from formulating criticisms towards the socialist world led by the U.S.S.R that had produced the Berlin Wall and the invasion of Czechoslovakia.

There is an important quantity of cables that mention Dom Hélder, reports about his speeches, public declarations and conversations with him. This indicates that, on one hand, the American officers had weighted well his relevance, yet on the other hand, Dom Hélder was a constant concern for the U.S. One of his speeches that riveted the attention of U.S. diplomats was delivered on May 2 of 1965 in Recife at the inauguration of the Northeastern Regional Seminary. On that occasion, the Minister Consul General Edward J. Rowell paid particular attention to the criticisms of the bishop to the developed countries and their "anti-American implications."

Rowell seems to catch a contradiction in Dom Hélder's behavior: "Despite the tone of the speech he went out of his way to greet publicly the presence of [the American Catholic] Bishop Carroll and to thank the American hierarchy for its aid to the Seminary." This suggests that for the officer, it was difficult to differentiate between an intellectual criticism of the U.S. and personal resentment toward U.S. citizens or Church. The cable follows: "Dom Hélder shows no signs of abandoning his views of the Church's

${ }^{178}$ Rocha, Hélder, o Dom, 29. 
role as an instigator of change and reform in society, nor his quasi-Marxist or---perhaps more accurately---“colonial” view of world affairs." The officer also depicts the bishop as an egocentric whose expressions of humility are ostentatious.

The paternalistic character of the National Security ideology is evident in Rowell's comments: “Although observers' views of his personality differ, the reporting officer, at least, finds what might otherwise be an obnoxious egotism much mitigated by an almost child-like enthusiasm and delight in what he is doing." ${ }^{\prime 179}$ The cable also refers to a recent travel of the bishop to France where he had received ovations. This comment points out that by 1965 , Dom Hélder was already being traced by the U.S. intelligence and/or diplomacy as a figure with international relevance.

Part of the power of Dom Hélder was his good relations with the Vatican. Since he and monsignore Giovanni Montini met in 1950 in Rome, the two churchmen had cultivated a strong friendship. As important members of the Catholic Action in their respective countries, they had common grounds. Montini, first as Vatican's Secretary of State and as Pope Paul VI after, had been a loyal supporter of the initiatives of the Brazilian bishop. All those elements were continuously weighted in the American cables of the time.

For the U.S., the political strength and public postures of Dom Hélder were the main referent for the rest of the progressive wing. Consequently, the conflicts that involved the Brazilian security forces with the bishop had deep consequences for the

\footnotetext{
${ }^{179}$ Report, Recife, May 11, 1965, State Department Cables, U.S. Embassy, Brasilia, National Archives, box
} 5. 
general relations between Church and state. The public declarations of Dom Hélder were usually taken as battle cries that incited the progressives to intensify their criticisms towards the regime. Occasionally, the opinions of the bishop would be interpreted in U.S. diplomatic communications as erroneous interpretations of reality.

That was the interpretation of ambassador Tuthill of Dom Hélder's criticisms of the failures of the Superintendency for the Development of the Northeast (Superintendência do Desenvolvimento do Nordeste, SUDENE) in 1968. In a cable of May 31, the ambassador endorsed a report that interpreted the criticism of Dom Hélder to SUDENE as the consequence of a misunderstanding by the bishop of the obstacles that the government faced in its efforts to develop the region. ${ }^{180}$

The American collaborationist approach to the Church that timidly emerged in the aftermath of the AI5 was also applied to Dom Hélder. In a cable of January of that year, the Consulate in Recife showed itself willing to have a good relation with the bishop. The telegram referred to a cordial conversation between the officers of the Consulate and Dom Hélder in which the latter said "he understood officials and communications media in US had taken stand critical of recent events with media particularly critical." ${ }^{181}$ The bishop also showed comprehension for the "difficult position" in which the U.S. was placed (see pp. 65-68). This indicates the willingness of both Dom Hélder and the Consulate to establish a fluent dialogue.

\footnotetext{
${ }^{180}$ Report, Recife, May 31, 1968, State Department Cables, U.S. Embassy, Brasilia, National Archives, box 24.

181 Telegram, Recife, January 4, 1969, State Department Cables, U.S. Embassy, Brasilia, National Archives, box 33 .
} 
Yet, Dom Hélder remained an undesirable element for the U.S. In March of 1969, during a graduation ceremony in the Catholic University of São Paulo, Dom Hélder made "a strident call for basic reforms in Brazil." ${ }^{182}$ In April, the Consulate of Recife reported acts of violence and terrorism from the extreme right in which elements of the Command of Communist Hunting (Comando de Caça aos Comunistas, CCC) took part with the acquiescence of military authorities in Recife; the telegram alerted readers that the "situation is further complicated by Archbishop Dom Helder Camara's recent more bellicose posture [that] clearly indicates willingness to risk confrontation with government over student issue." ${ }^{, 183}$ Naturally, the "student issue" in this context means support of the student movement in spite of the disapproval of the regime. Later on, the Consulate reported that the bishop "used the occasion of masses on June 27 commemorating the 30-day anniversary of the murder of Father Antonio Henrique Pereira Neto again to speak out publicly against the prevailing political situation." ${ }^{184}$

Dom Hélder was the enemy number 1 of the military regime. The murder of father Henrique was the height of a systematic campaign against the bishop that included mortal threats, machine-gunning of his house and other intimidating tactics. Moreover, the military and the U.S. officers expected that the repression of the progressive Catholic grassroots movement would undermine the power of the bishop. Conversely, the military

\footnotetext{
${ }^{182}$ Report, Recife, March 20, 1969, State Department Cables, U.S. Embassy, Brasilia, National Archives, box 32 .

${ }^{183}$ Telegram, Recife, April 30, 1969, State Department Cables, U.S. Embassy, Brasilia, National Archives, box 33 .

${ }^{184}$ Report, Recife, July 7, 1969, State Department Cables, U.S. Embassy, Brasilia, National Archives, box
} 33 . 
contributed to making of Dom Hélder a worldwide prophet and a symbol of religiousbased opposition to the status quo.

The Department of State had always been watchful of the travels of Dom Hélder, particularly to the U.S. In November of 1969 , an officer of the Consulate of Recife visited the bishop in the Archbishop's palace and asked him about his plans for travel to North America and Europe scheduled for January of 1970. The officer was not only interested in the content of the bishop's message, but also in the funding for the travel as suggested by the mention of the matter in the cable: "According to Dom Hélder, his visits to Canada and the United States will be sponsored by "church groups and universities," including the University of Detroit and Columbia University." 185

The international prophetic mission of Dom Hélder caught even greater attention of the U.S. Service in 1970. ${ }^{186}$ The "low key" posture of the Church, adopted since 1969 and made official in the CNBB meeting of February of 1970, had reduced the capacity of communication of Dom Hélder, the clearest individual voice of the Church. More importantly, the military expressly prohibited the reproduction of Hélder's statements or even the mention of his name in the media. Consequently, the bishop had to find his audience in the international community.

Interestingly enough, the U.S. was for Dom Hélder a place of free speech, where he was not submitted to the sort of attacks that he was used to facing in his own country.

\footnotetext{
${ }^{185}$ Report of conversation, Recife, December 2, 1969, State Department Cables, U.S. Embassy, Brasilia, National Archives, box 32.

${ }^{186}$ Report of conversation, Recife, May 7, 1970, State Department Cables, U.S. Embassy, Brasilia, National Archives, box 39.
} 
After a conversation of Dom Hélder with ambassador Elbrick, the consul Donor Lion and another officer of the Consulate, in August of 1969, the diplomatics noted: "Dom Hélder remarked that it was ironic that the American Ambassador and other US. Government officials in Recife were unafraid to meet with him while many Brazilian authorities, both civil and military seemed intimidated."

As in many other conversations with American officers, Dom Hélder did not hide his criticisms to the dictatorship's "failure to implement basic reforms." Moreover, the bishop always expressed his conviction of the potential of the U.S. to influence positively the Brazilian regime. With this outlook, the bishop tried to influence the American posture without expressing his criticisms to the U.S. in a negative way: "He claims that the US must bear a large measure of responsibility for correcting these injustices in Latin America since, whether the Latins like it or not, they are part of the United States' zone of influence." ${ }^{\prime 188}$ Though not obviously, the reproach was always there.

Dom Hélder took abroad his discourse of non-violence and social justice. In United States, he not only addressed the problems of his country and the third world but also talked openly about the Vietnam War and the threat to democracy that the “industrial-military complex" represented. ${ }^{189}$ His impact in the U.S. was important; the bishop was central in the conformation of religious-academic networks that denounced

\footnotetext{
187 Report of conversation, Recife, August 20, 1969, State Department Cables, U.S. Embassy, Brasilia, National Archives, box 34.

188 Report of conversation, Recife, March 2, 1970, State Department Cables, U.S. Embassy, Brasilia, National Archives, box 42.

189 Report of conversation, Recife, December 2, 1969, State Department Cables, U.S. Embassy, Brasilia, National Archives, box 32.
} 
the Brazilian situation in the U.S. and Europe. ${ }^{190}$ Dom Hélder also had close ties with the Civil Rights Movement ${ }^{191}$ and leaders like the priest and activist Phillip Berrigan and his movement of denunciation of the Vietnam War. ${ }^{192}$

The U.S. officers were aware of the success with which the "itinerant and highly controversial" bishop was denouncing the atrocities of the regime abroad. A cable of November of 1970 reported the accusations made by the Governor of São Paulo, Roberto de Abreu Sodré, against Dom Hélder after the Governor's visit to Europe: “Apparently the Governor came back in a state of high pique consequent to the atmosphere of misunderstanding and hostility to Brazil he encountered in some quarters in Western Europe, notably in youth and journalistic circles."193 The U.S. officers followed all the controversy in the course of which Abreu Sodré called the bishop a "Fidel Castro in cassock" and Cardinal Rossi interceded on behalf of Dom Hélder. That was only one example of the many attacks to Dom Hélder from the Brazilian establishment that strengthened the notion of Dom Hélder as a persecuted dissident.

The monitoring of the activities of Dom Hélder, in Brazil and abroad, continued during 1971 and 1972. By that time, the bishop was already regarded as a prophet of his time. The U.S. consular view of him combined an awareness of his historical relevance

\footnotetext{
${ }^{190}$ Green, We Cannot Remain Silent, 332.

191 Telegram, Recife, July 21, 1970, State Department Cables, U.S. Embassy, Brasilia, National Archives, box 39 .

192 José de Broucker, Dom Helder Camara; The violence of a peacemaker (Maryknoll, N.Y.: Orbis Books, 1970), 79 .

${ }^{193}$ Report, São Paulo, November 3, 1970, State Department Cables, U.S. Embassy, Brasilia, National Archives, box 39 .
} 
with the reservations that are already clear. In a cable issued in Washington on June of 1971, George Lister, a central figure in the human rights policy of the State Department, expressed a desire to meet the bishop; this was in the framework of an eventual trip of Dom Hélder to Washington (finally aborted), where he had some academic and religious commitments sponsored by the National Office for Black Catholics. ${ }^{194}$

The contact of Dom Hélder in Washington was Brady Tyson, a Methodist missionary and academic who was living in São Paulo at the time of the coup d'état but had left Brazil in March of 1966 due to pressures from the regime. ${ }^{195}$ Tyson was an active part of the international academic-religious network of denunciation and opposition to the Brazilian dictatorship, and would later join the diplomatic corps during the Jimmy Carter administration.

The last cable of the 1964-1972 period that deals entirely with Dom Hélder, dates from August of 1972. In the report of a conversation, the recently appointed Consul of Recife, Calvin C. Berlin, commented on the current situation of Dom Hélder: "He gives the impression of being quite isolated from both official circles and sources of influence, a position that attests to the effectiveness of the government in cutting off his lines of communication. His ready accessibility may be due in large part to the fact that many

\footnotetext{
${ }^{194}$ Report, Washington, June 16, 1971, State Department Cables, U.S. Embassy, Brasilia, National Archives, box 51 .

${ }^{195}$ Green, We Cannot Remain Silent, 63-64.
} 
people hesitate to seek him out for fear of adverse repercussions on the part of the government." $" 196$

${ }^{196}$ Report of conversation, Recife, August 24, 1972, State Department Cables, U.S. Embassy, Brasilia, National Archives, box 68 . 


\section{CHAPTER 6}

\section{Conclusions}

The Catholic Church was an important factor in the history of Brazil during the twentieth century. As a consequence of its involvement in the public life, a myriad of worldviews that can be interpreted as different political positions abounded in the Brazilian Church. In this context, a vital progressive movement emerged within the Church in the 1940s and 1950s. One principal factor in this development was the constant influx of European and North American priests. Foreign priests have had a significant presence in the Brazilian Church and were channels for the spread of avant-garde French Catholic ideas in Brazil.

A common element of the French school was the importance given to the lay apostolate and the active dialogue with modern narratives. This was the basis for the development of Catholic Action, a group of lay organizations mainly constituted by young workers and students. Gradually, progressivist thought permeated all sectors of the Church, including the episcopate, but strengthened particularly within the orders and the Northeast region. Those sectors developed a social commitment to the subordinate classes and an ethical criticism of inequality, social injustice and oppression. As a result, the Catholic Church built strong ties with other progressive sectors of society, such as students, intellectuals and statesmen. 
During the 1960s, in the aftermath of the Cuban Revolution, the forces of change, including the Catholic progressivism, got caught amidst a violent political confrontation that would prove definitive for the history of Latin America. United States was a principal instigator of this conflict. In the framework of the imperialist relations with Latin America, the U.S. spread the Doctrine of National Security as a means to maintain its hegemony in the region. The Doctrine, an international version of McCarthyism, was used to squash the progressive thought through the continent.

The Doctrine, characterized by authoritarianism, paternalism and Manichaeism, fit well in the mind of the Latin American military. During the 1960s and 1970s, the United States encouraged, supported and at times arranged the imposition of military dictatorships in the Southern Cone. These dictatorships employed policies of terror and dirty war to destroy revolutionary and liberationist movements. Churchmen, intellectuals, and especially students, were the targets of the repression. The coup d'état that installed a 20 year long dictatorship in Brazil in 1964, though orchestrated from the Brazilian military, was part of that broader process.

Unable to distinguish among its enemies, and imbued with the Manichaean ideology of National Security, the dictatorship massively employed repression against the Catholic Church. Although the military were successful in undermining the Catholic grassroots, they actually generated an unfavorable attitude in most segments of the Church, including the powerful bishops. As a consequence, the first five years of dictatorship were characterized by several confrontations between the Church and the regime. 
According to the lines of National Security, during this time the United States developed a great interest in the progressive sectors of Brazilian Catholicism, namely the Catholic Action movement, foreign priests and the bishops of the Northeast among others. Those sectors had the capacity to carry out important reforms in Brazil but were thought to be a threat to the interests of the U.S. The Catholic Action movement, one of the most progressive experiments in the history of the Church, was regarded as a factor of communist infiltration. Particularly alarming were the sympathies between churchmen and students, latter being anathema for National Security. During the repression of the student movement between 1966 and 1968, the State Department got very interested the São Bento Monastery, the orders and some bishops who supported and protected the youth from the state repression.

Since most of the progressive movement was grounded in the Northeast dioceses, that region captured most of the attention of the U.S. The indisputable leader of the movement was the charismatic bishop of Olinda and Recife, Dom Hélder Câmara. This worldwide famous religious leader was for the U.S. the reference for the whole progressive movement. The cables of the American posts in Brazil during that time exude disapproval and even animosity towards this bishop, who was seen as a dangerous figure. During the 1964-1972 period, the U.S. followed closely the steps and words of Dom Hélder in Brazil and abroad. His dangerousness rested both in his prophetic mission and the wide recognition he enjoyed nationally and internationally. His criticisms of the status quo and denunciations of the repressive character of the regime, as those of the other progressive leaders of the Church, were for the U.S. undesirable acts of war. 
"Church-state relations" was the overarching element of the American worries in regards to the Brazilian Church. It was a common label in boxes, folders and cables in the archives of the communications with the Foreign Mission in Brazil. Bearing in mind that during this period those relations were characterized by political conflict, the Church was, for the U.S, a destabilizing element for a military dictatorship that was seen, ironically, as defender of liberty and democracy. In regard to the public confrontations between both institutions, the American diplomats showed concern for how these conflicts undermined the image and legitimacy of the military. That explains the deep interest of the U.S. in the official positions of the CNBB toward the regime during the meetings of the episcopate.

The United States was ideologically and politically committed to the Brazilian dictatorship from the very beginning. Therefore, the State Department's interpretation of the Church was dictated by the American concern for the preservation of the regime rather than for justice and democracy. The interests and concerns of the U.S. officials must be contrasted with those important elements that are absent in the cables or that only obliquely receive attention. The "Church-state relations" approach is in some way deceitful. It implies the perception of a conflict between two equal parts; the reporting of Church-state relations has the appearance of a neutral assessment, based on a preoccupation with the preservation of democracy and stability in Brazil. But this objective language actually obscures the reality of the political persecution of the Church along with other organized groups by the military.

Acts of violence against the Church were not a concern for the U.S., as a long as they did not represent a public confrontation capable of garnering new opponents of the 
military. When reporting about arrests, detentions, torture and censorship, the officers invariably focused on how those events would be used to "criticize the government." In that way, violations of human rights and the political persecution of the Church were highly hidden in the cables. That political commitment of the U.S. with the military regime was evident especially in the cables about the murder of father Henrique Pereira Neto in May of 1969.

The American "Church-state relations" approach entails an irony. The physical and symbolic violence against the Church was less important than the public reaction of the Church or any of its members. In other words, the linguistic performances of the churchmen, such as speeches and public letters, and the journalistic coverage about them, were for the U.S. a more important element of the political struggle than torture and political persecution. The symbolic acts of the Church were regarded as "bellicose" statements that were used as weapons in leftist attacks against the regime. On the other hand, the military, at least in these cables, was presented chiefly as a rational and voiceless entity.

The fact that public statements by bishops were, in the American view, the central element in the Church-state conflict brings up the relevance of the press. Newspapers were the space par excellence in which the public statements and letters of the bishops appeared. Particularly in the years prior to the imposition of full censorship, the press was the field in which the political confrontation took place. The enormous capacity of public opinion to affect the regime was demonstrated by the heavy efforts of the military in 
imposing censorship. As any other authoritarian regime, the Brazilian dictatorship made an enormous effort to hide its atrocities.

Besides personal conversations between the American officers and well-informed people, the press was the principal source of information for the U.S. about the Churchstate conflict. Obviously, part of the job of the officers was to submit the information that they gathered to critical analysis and contrast it with human sources. The analytical process allowed the officers to interpret reality more deeply than any newspaper. Still the reliance of American reporting officers upon the press confirms the centrality of mass media as a channeling element of public attention.

The cables about bishop Dom Hélder Câmara are an example of how the American view of the Church was heavily influenced by the media. Most of the time, the bishop was described as "controversial" or even "highly controversial." Controversy refers directly to a public matter, a public opposition that, at least until 1968, took place in the press field or was reproduced by the press. Therefore, the American view of Dom Hélder was highly influenced by the characterization that newspapers made of him.

The interest of the U.S. in the Church, as any historical phenomenon, was neither static nor absolute. National Security did not account for the whole American view of the Church during those years. According to the cables, another view became very important after the radicalization of the dictatorship on December of 1968 when persecution became systematic and repression an official policy. This had as a consequence an increasing rejection of the Brazilian regime in the international scenario, namely in the United States and Europe. In this context, the Church opted for avoiding individual 
confrontations with the military but adopted a policy of total opposition to the anti-human rights policy of the regime. That opposition resulted in protection of dissidents in Brazil and denunciation of the situation abroad.

Then, the American interest had a subtle change. Besides the "Church-state relations," an idea of the Church as a fundamental element for social change in Brazil emerged. This ignited a systematic effort to gather information and seek bilateral dialogue with the most conspicuous members and sectors of the Church. It was a pragmatic approach. As a prime order institution, with national reach that crosses all regions, classes, genres and political ideas, the Church was seen as a potential node for the U.S. intervention in Brazil.

The "collaboration for social change" attitude of the kind of the Alliance for Progress has never been at odds with authoritarianism. Both are part of a historical dialectic present across the different aspects of the U.S. hegemony in Latin America that is commonly known as "carrot and stick approach." Historically, when the U.S. refers to social change in Latin America, this means a very gradual process carried out through modernization and intended to appease progressive, liberationist and revolutionary movements.

In sum, the American view of the Catholic Church in Brazil was determined by the political commitment of the United States to the Brazilian dictatorship. During the 1964-1972 period the interest was ruled by the ideology of National Security Doctrine and the pragmatic need to establish collaborative relations with the most powerful sectors of Brazil. The understanding of the first approach is particularly important to understand 
the changes in the religious-political arena of Brazil and Latin American during the 1970s and 1980s. Those were years characterized by an ecclesiastical and political reaction against the progressive sectors of the Catholic Church.

\section{Further Research Possibilities}

Further research endeavors in the field intended to deal with the political repression of Liberation Christianity and Liberation Theology should contain the continental perspective in which United States played an important role. Some of those endeavors could contain information from thus far classified information of the State Department and the CIA, which have been protagonists in the political and religious conflicts of Latin America for more than fifty years, though sometimes their involvement is obscured. Moreover, any research that uses cables of the American Foreign Service should include a call to question the legitimacy of the hegemonic presence of the U.S. in foreign countries through its diplomatic apparatus.

Interestingly enough, the "Church-state relations" approach, so present in the cables used for this research, remains in the American scholarship about this important period of Brazilian history. The question arises as to whether this approach in the academic community still contains the methodological problems that became clear in this thesis. Meanwhile, I am hopeful that with this research I have contributed to the understanding of the international aspects of the Brazilian Catholic Church during the times of the dictatorship in which the works of Penny Lernoux and James Green remain so important. 
The international approach should also contribute to understand the successes and failures of the progressive and liberationist national movements in Latin America. The deeds of the Brazilian Catholic Church during the dictatorship have had enormous consequences that have continued until today. The same judgment applies to Ecuador and Bolivia in which the Church helped to form the basis of deep processes of renovation that continue to the present day. Comparative works could help us understand how the different situations and behavior of the historical actors had positive and negative consequences for the social change and the still so unhopeful present of most of Latin America. 


\section{BIBLIOGRAPHY}

\section{Primary Sources}

Galbraith, Peter W. "How to Write a Cable: A veteran diplomat explains how it's really done." Foreign Policy, February 22, 2011. Accessed February 9, 2014. http://www.foreignpolicy.com/articles/2011/02/22/how to write a cable

National Archives. "Foreign Affairs and International Topics." Last modified February 9, 2014. http:/www.archives.gov/research/foreign-policy/index.html

National Security Archive - George Washington University. "Kubark Counterintelligence Interrogation." Last modified February 9, 2014. http://www2.gwu.edu/ nnsarchiv/NSAEBB/NSAEBB27/docs/doc01.pdf

. "Brazil Marks 40th Anniversary of Military Coup: Declassified documents shed light on U.S. role." Last modified February 9, 2014. http://www2.gwu.edu/ nsarchiv/NSAEBB/NSAEBB118/\#audio

Office of the Historian - U.S. Department of State Archive. "Foreign Relations, 19641968, Volume XXXI, South and Central America; Mexico.” Last modified February 9, 2014. http://2001-2009.state.gov/r/pa/ho/frus/johnsonlb/xxxi/36365.htm

Records of the Foreign Service Posts of the Department of State. U.S. Embassy, Brasilia. National Archives. College Park, Maryland.

\section{Secondary Sources}

Alves, Márcio Moreira. 1979. A Igreja e a Politica no Brasil. São Paulo: Editora Brasiliense.

Alves, Maria Helena Moreira. 1985. State and Opposition in Military Brazil. Austin: University of Texas Press.

Antoine, Charles. 1973. Church and Power in Brazil. Maryknoll, NY.: Orbis Books.

Beozzo, José Oscar. 1984. Cristãos na Universidade e na Política: História da JUC e da $A P$. Petrópolis: Vozes. 
Bidegain, Ana Maria. 1979. La Organización de Movimientos de Juventud de Acción Católica en América Latina: Los casos de los obreros y universitarios en Brasil y Colombia entre 1930 - 1955, parte III (Brasil.) PhD diss., Catholic University of Louvain.

. 1985. From Catholic Action to Liberation Theology: The historical process of the laity in Latin America in the twentieth century. Notre Dame, IN.: Helen Kellogg Institute for International Studies, University of Notre Dame.

Blum, William. 2004. U.S. Military and CIA Interventions since World War II. Monroe, Me.: Common Courage Press.

Broucker, José de. 1970. Dom Helder Camara: The violence of a peacemaker. Maryknoll, N.Y.: Orbis Books.

Bruneau, Thomas. 1974. The Political Transformation of the Brazilian Catholic Church. London: Cambridge University Press.

. 1982. The Church in Brazil: The politics of religion. Austin: University of Texas Press.

Burns, Bradford. 1993. A History of Brazil. New York: Columbia University Press.

Camargo, Cándido Procópio Ferreira de, Souza, Beatriz Muñiz de, Pierucci, António Flávio de Oliveira and Jasís, Mónica. "La Iglesia Católica en el Brasil: 19451970.” Revista Mexicana de Sociología, Vol. 43, Número extraordinario (1981): 1999-2041.

Cardoso, Fernando Henrique and Faletto. 1973. Dependência e Desenvolvimento na América Latina: Ensaio de interpretação sociológica. Rio de Janeiro: Zahar Editores.

Casanova, José. 1994. Public Religions in the Modern World. Chicago: University of Chicago Press.

Dávila, Jerry. 2013. Dictatorship in South America. Malden, Ma.: Wiley-Blackwell.

Della Cava, Ralph. 1988. The Church and the Abertura in Brazil, 1974-1985. Notre Dame, IN.: Helen Kellogg Institute for International Studies, University of Notre Dame.

Dreifuss, René. 1981. 1964, a Conquista do Estado: Ação política, poder e golpe de classe. Petrópolis: Vozes.

Drogus, Carol Ann. 1997. Women, Religion, and Social Change in Brazil's Popular Church. Notre Dame, IN.: University of Notre Dame Press.

Dussel, Enrique. 1981. A History of the Church in Latin America: Colonialism to liberation. Grand Rapids, MI.: William B. Edermans. 
Fico, Carlos. 2008. O Grande Irmão: Da operação Brother Sam aos anos de chumbo. O governo dos Estados Unidos e a ditadura militar brasileira. Rio de Janeiro: Civilização Brasileira.

Gill, Anthony J. "Rendering unto Caesar? Religious Competition and Catholic Political Strategy in Latin America, 1962-79." American Journal of Political Science, Vol. 38, No. 2 (May, 1994): 403-425.

Gill, Lesley. 2004. The School of the Americas. Durham, NC. and London: Duke University Press.

Gómez de Souza, Luis Alberto. 1982. Classes Populares e Igreja nos Caminhos da História. Petrópolis: Vozes.

1984. A JUC: Os estudantes católicos e a política. Petrópolis: Vozes.

Green, James. "Clerics, Exiles, and Academics: Opposition to the Brazilian military dictatorship in the United States, 1969-1974." Latin American Politics and Society, Vol. 45, No. 1 (Spring, 2003): 87-117.

. 2010. We Cannot Remain Silent: Opposition to the Brazilian military dictatorship in the United States. Durham, NC.: Duke University Press.

Klein, Naomi. 2007. The Shock Doctrine: The rise of disaster capitalism. New York: Metropolitan Books/Henry Holt.

Krischke, Paulo. 1979. A Igreja e as Crises Políticas no Brasil. Petrópolis: Vozes.

and Castro, Bruno Alves de. "Brasil: Problemas teóricos de las relaciones entre la Iglesia y el estado en la crisis de 1964." Revista Mexicana de Sociología, Vol. 43, Número extraordinario (1981): 2043-2067.

Lernoux, Penny. 1980. Cry of the People: United States involvement in the rise of fascism, torture, and murder and the persecution of the Catholic Church in Latin America. Garden City, NY.: Doubleday \& Company.

Levine, Daniel. 1980. Churches and Politics in Latin America. Beverly Hills: Sage Publications.

. 1986. Religion and Political Conflict in Latin America. Chapel Hill: University of North Carolina Press.

. 2012. Politics, Religion, and Society in Latin America. Boulder, Colo.: Lynne Rienner Publishers.

- and Mainwaring, Scott. 1986. Religion and Popular Protest in Latin America. Notre Dame, IN.: Helen Kellogg Institute for International Studies, University of Notre Dame. 
Lima, Medeiros and Lima, Alceu Amoroso. 1973. Memórias Improvisadas: Alceu Amoroso Lima. Petrópolis: Vozes.

Löwy, Michael. 1996. The War of Gods: Religion and politics in Latin America. London: Verso.

Mainwaring, Scott. 1986. The Catholic Church and Politics in Brazil, 1916-1985. Stanford: Stanford University Press.

Mendes, Cândido, and Bandeira, Marina. 1996. Comissão Brasileira Justiça e Paz (19691995): Empenho e memória. Rio de Janeiro: Educam.

Morais, Régis de. 1982. Os Bispos e a Política no Brasil: Pensamento social da CNBB. São Paulo: Cortez Editora.

Moran, William et al. 1987. Les Letres d'el-Amarna: Correspondance diplomatique du pharaon. Paris: Ed. Du Cerf.

Muehlenbeck, Philip E. 2012. Religion and the Cold War: A global perspective. Nashville: Vanderbilt University Press.

Regan, David. 2002. Why are They Poor?: Helder Camara in pastoral perspective. Münster: Lit.

Rocha, Zildo. 1999. Hélder, o Dom: Uma vida que marcou os rumos da Igreja no Brasil. Petrópolis: Vozes.

Rubenstein, Richard L. and Roth, John K. 1988. The Politics of Latin American Liberation Theology: The challenge to U.S. public policy. Washington, D.C.: Washington Institute Press.

Scatena, Silvia, Sobrino, Jon, and Susin, Luiz Carlos. 2009. Fathers of the Church in Latin America. London: SCM Press.

Schoultz, Lars. 1981. Human Rights and United States Policy toward Latin America. Princeton: Princeton University Press.

Serbin, Kenneth. "The Anatomy of a Death: Repression, human rights and the case of Alexandre Vannucchi Leme in authoritarian Brazil." Journal of Latin American Studies, Vol. 30, No. 1 (Feb., 1998): 1-33.

.2000. Secret Dialogues: Church-state relations, torture, and social justice in authoritarian Brazil. Pittsburgh, Pa.: University of Pittsburgh Press.

Smith, Brian H. "Churches and Human Rights in Latin America: Recent trends in the subcontinent." Journal of Interamerican Studies and World Affairs, Vol. 21, No. 1, Special Issue: The Church and Politics in Latin America (Feb., 1979): $89-127$. 
Vásquez, Manuel. 1998. The Brazilian Popular Church and the Crisis of Modernity. Cambridge: Cambridge University Press.

Vilar, Constance. 2008. Le Discours Diplomatique. Paris: Université de Bordeaux et L'Harmattan. 
APPENDICES 
Appendix 1: Cable from Washington to Ambassador Gordon during the coup d'état

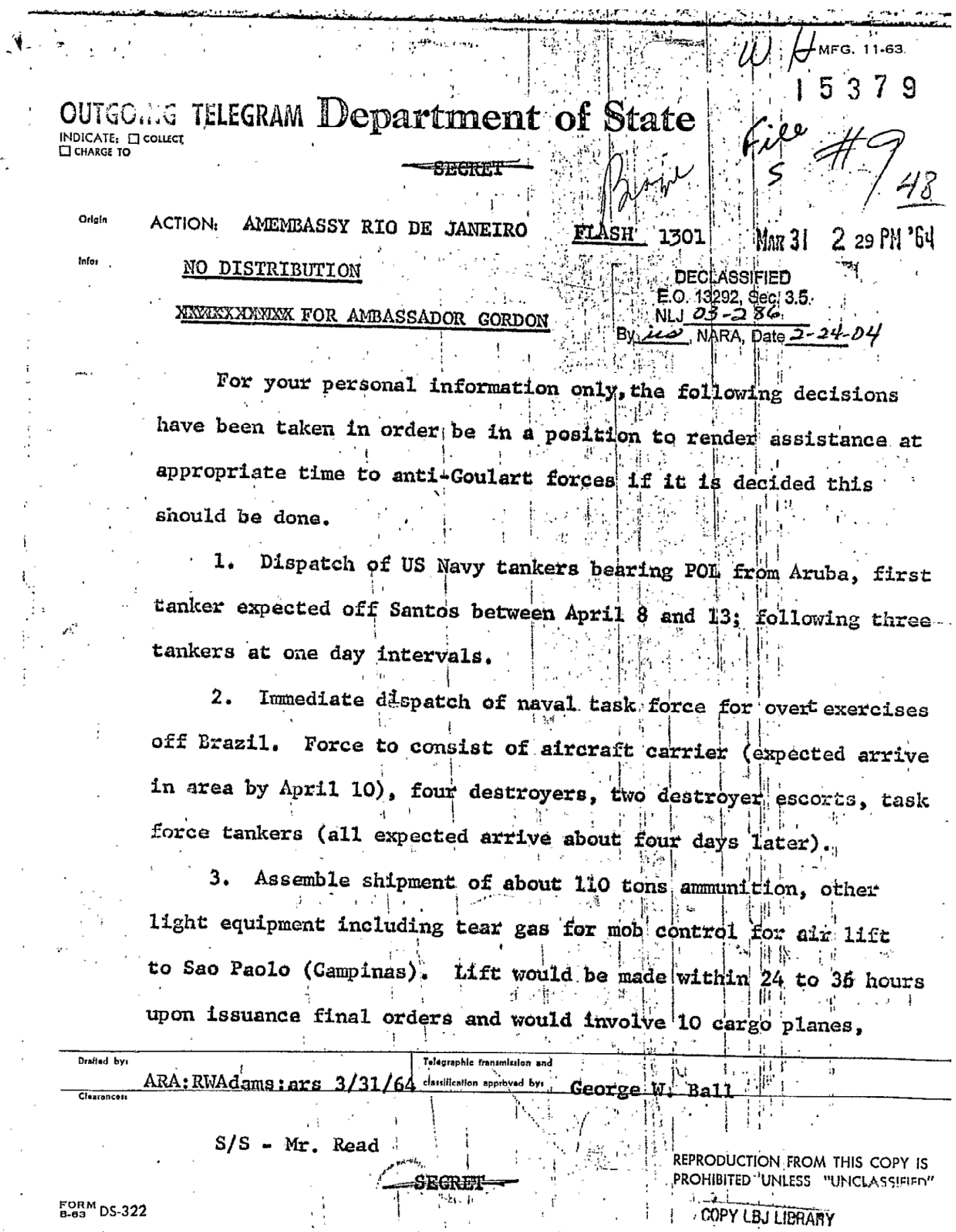




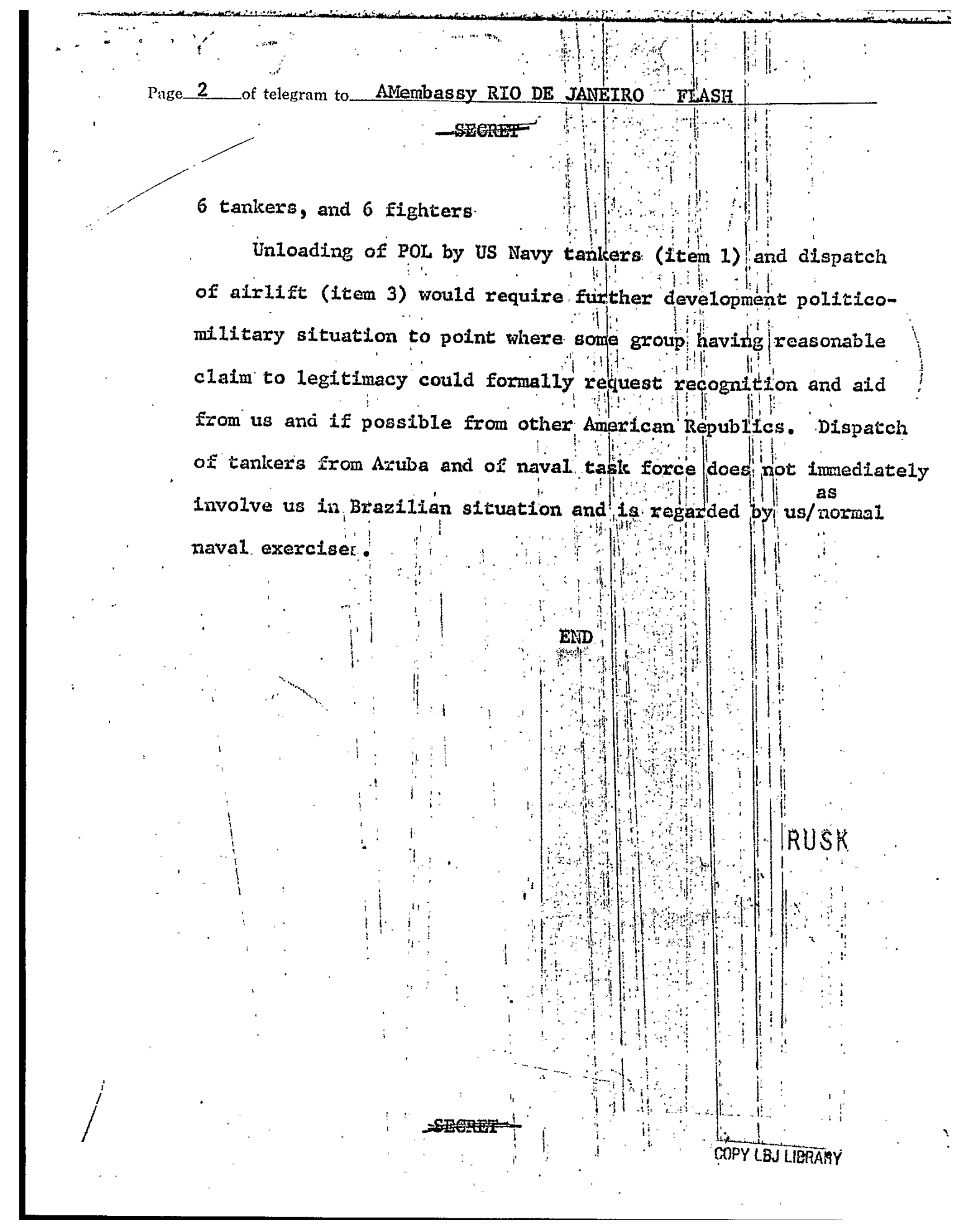


Appendix 2: Distribution of cables by months and years

\begin{tabular}{|l|r|r|r|r|r|r|r|r|r|r|}
\hline MONTH/YEAR & 1964 & 1965 & 1966 & 1967 & 1968 & 1969 & 1970 & 1971 & 1972 & \\
\hline January & 2 & & & & & 7 & 1 & & 1 & \\
\hline February & & & & & & 11 & 2 & 5 & & \\
\hline March & & & & & 1 & 3 & 3 & 3 & & \\
\hline April & & & & & 3 & 4 & 3 & 2 & 3 & \\
\hline May & & 2 & & & 2 & 5 & 5 & & & \\
\hline June & 3 & 2 & & & 1 & 6 & 3 & 1 & 2 & \\
\hline July & & & & & 1 & 7 & 4 & 1 & 7 & \\
\hline August & 2 & & 3 & & & 7 & & 2 & 3 & \\
\hline September & & & & & 2 & 2 & 3 & 4 & 2 & \\
\hline October & & & & & & 1 & 9 & 1 & 1 & \\
\hline November & & & & & & 3 & 6 & & 1 & \\
\hline December & & & & & 1 & 5 & 3 & & & \\
\hline Total Docs & 7 & 4 & 3 & & 11 & 61 & 42 & 19 & 20 & 167 \\
\hline Total Pages & 28 & 14 & 11 & & 54 & 249 & 110 & 54 & 32 & 552 \\
\hline
\end{tabular}


Appendix 3: First page of cable (August 19, 1966)

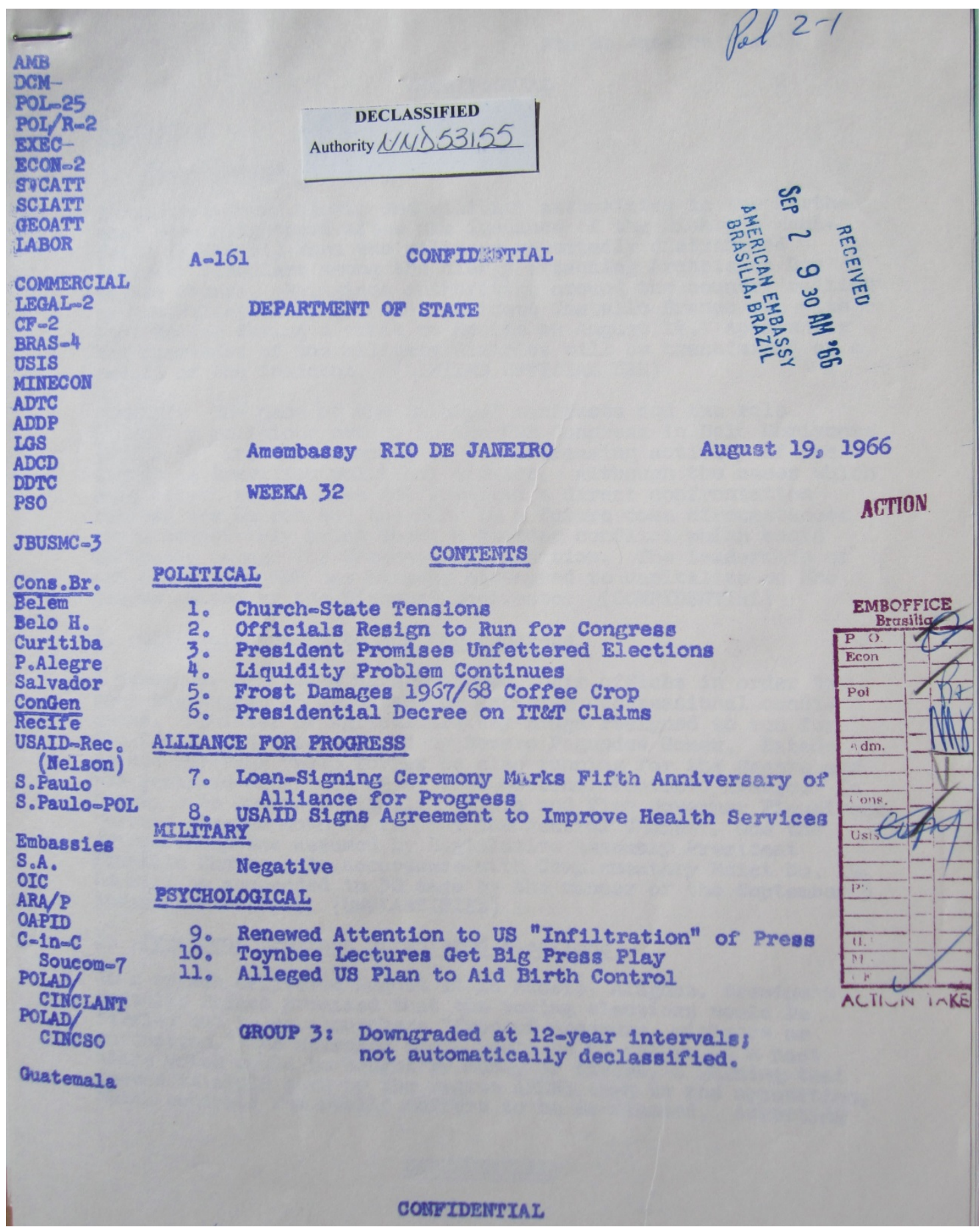




\section{Appendix 4: First page of cable (August 26, 1966)}

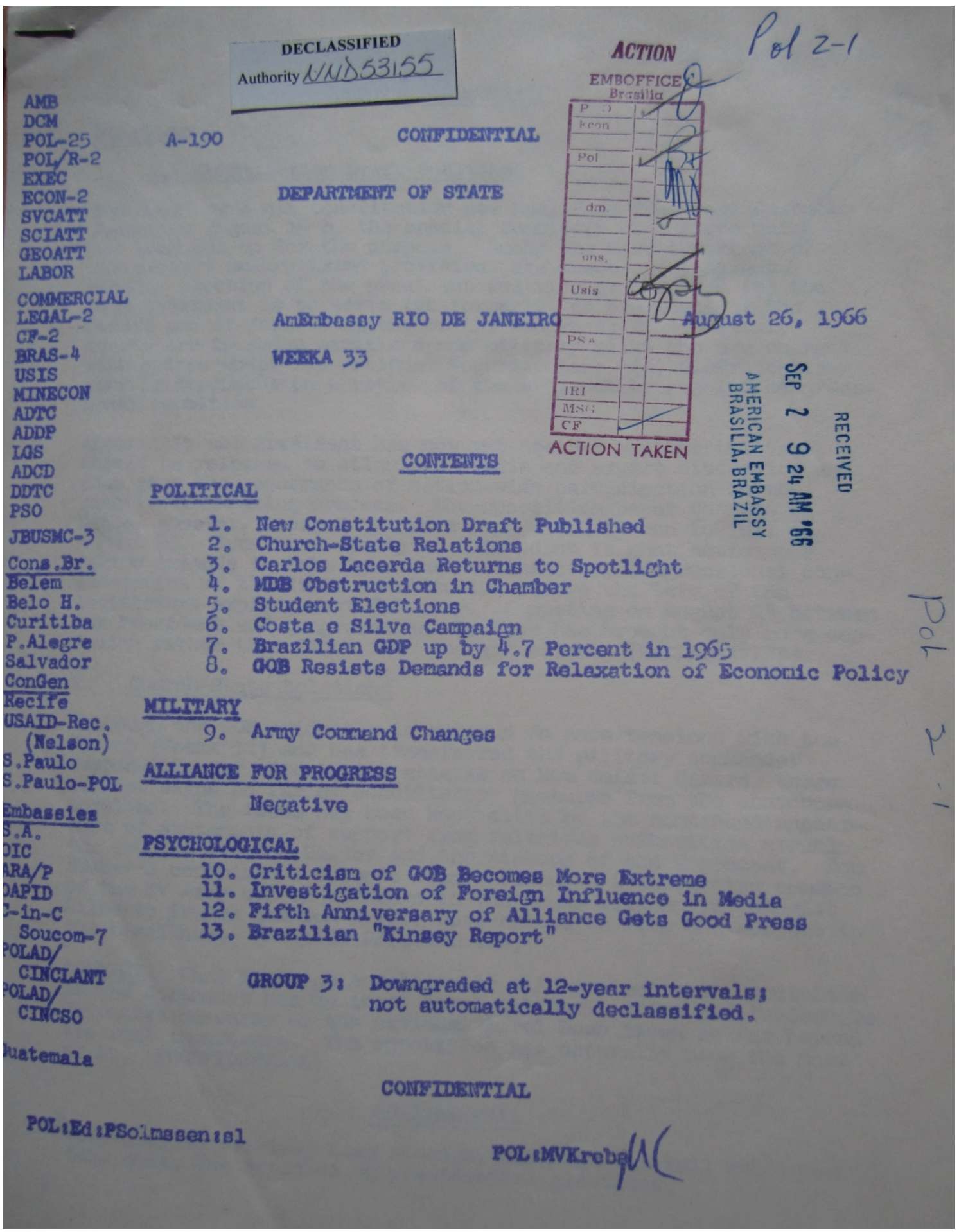

